\title{
Assessment of Residual Load-Bearing Capacity of Induced Corrosion on Reinforced Concrete Members
}

\author{
Charles Kennedy ${ }^{1}$, Ugo Kingsley ${ }^{2}$, Overo Kenneth Ejulkonemu ${ }^{3}$,
${ }^{1}$ Faculty of Engineering, Department of Civil Engineering, Rivers State University, Nkpolu,
Port Harcourt, Nigeria.
${ }^{2}$ School of Engineering, Department of Civil Engineering, Kenule Beeson Saro-Wiwa
Polytechnic, Bori, Rivers State, Nigeria
${ }^{3}$ Faculty of Engineering, Department of Civil Engineering, Niger Delta
University,Wilberforce Island, Bayelsa State
Authors E-mail:, ${ }^{2}$ ken_charl@ yahoo.co.uk, ${ }^{3}$ ugok1960c@gmail.com,
${ }^{3}$ kennethovero@gmail.com
}

ABSTRACT

This research evaluated the application of exudates/resins from naturally occurring plant extrudes with environmentally friendly characteristics of non-harmful materials obtained from tree trunks. The viscous exudates/resin was embedded in the concrete beam after coating of varying thicknesses applied directly to the steel reinforcement and evaluating its usefulness as corrosion-resistant to structures exposed to the harsh and severe environment of the coastal marine. From the flexural strength test, the maximum value was $28.38 \%$ compared to the corroded and coated sample values of $-21.04 \%$ and $27.47 \%$, respectively. The results showed a lower elongation load in the case of controlled and coated samples with a reduction value above the corrosion samples with higher elongation loads and increased values compared to the reference range (controlled) and coated samples. The comparison results obtained during and after the corrosion test the maximum value of the diameter of the anchor checked was $0.69 \%$ compared to the corroded one at $-0.91 \%$ and the sample with a coating of $1.11 \%$. The calculated mean differential and percentile values were checked $(0.02 \mathrm{kN}$ and $0.11 \%)$, corroded values were $(0.013 \mathrm{kN}$ and $0.1 \%)$, and coated values $(0.01 \mathrm{kN}$ and $0.11 \%$ ). The results showed that the effect of corrosion on the mechanical properties of reinforcing steel with a decrease in diameter reduced the average and percentage of samples corroded, while the controlled and coated samples showed a preserved state due to coating due to an increase in diameter different layer thicknesses with exudate/resin. The crosssectional area of reinforcing steel gives different mean and percentile values for corroded values $(0.02 \mathrm{~mm}$ and $4.51 \%)$ and coated values $(0.01 \mathrm{~mm}$ and $9.18 \%)$. Differential calculated mean and percentage values of yield strength and ultimate tensile strength are $(2.43 \mathrm{MPa}$ and $0.04 \%)$ and $(4.49 \mathrm{MPa}$ and $0.02 \%$ ) were examined, the corrosion value was $2.43 \mathrm{MPa}$ and $0.04 \%)$ and (4.5MPa.) and $0.03 \%$, the values covered are $(2.43 \mathrm{MPa}$ and $0.04 \%)$ and $(4.4 \mathrm{MPa}$ and $0.03 \%$ ). It was found that the ratio of the maximum calculated strain ratio for the mean and percentile values for the controlled was $-2.72 \%$ compared to the corroded and overlaid values of $2.51 \%$ and $-2.43 \%$, respectively. The mean differential and percentile values obtained for the control was $(0.01$ and $0.03 \%)$, corrosion values $(0.01$ and $0.02 \%)$ and values with coating ( 0.01 and $0.02 \%)$.

Key Words: Corrosion, Corrosion inhibitors, Flexural Strength, Concrete and Steel Reinforcement 


\section{INTRODUCTION}

The main durability problem associated with reinforced concrete structures built in the marine environment is the corrosion effect. Corrosion effects on the bond strength between steel and concrete, leading to durability and serviceability of reinforced concrete structures. Tensile stresses due to corrosion in steel reinforcement are produced in the environment of concrete structures, leading to initial cracking. In addition, steel reinforcement cross sectional - area reduction has been identified, which reduces the ductility of the structure, especially in the event of corrosion pitting, the increase in the size of the steel bars such as expansion and volume is the result of corrosion products, leading to the weakening of the reinforcing steel bar cross-sectional area. Reinforcement and concrete reduce the bonding rate, thereby creating stress in concrete environments, [1] found from studies of the impact of steel reinforcement corrosion and bond strength. This coincides with the experimental results obtained from the reinforced concrete beam tests, which increase the bond strength. The degree of corrosion is increased by $4 \%$ due to the radial pressure caused by the expansion of the corrosion products [2]. In agreement with the above results, significant literature has been published in this area ([4], [5], [6], [7] and [8]).

[9] Investigated the primary causes of service life, integrity and the ability of reinforced concrete structures in the marine environment of saline origin on corrosion. The overall results show a lower percentage and greater percentage of corrugated members. This justifies the effect of corrosion on the strength of corroded and coated members.

[10] Investigated the use of epoxy, resin / exudates to curb this tendency in the face of reinforced structures constructed, as reinforced corrosion in concrete is one of the major factors contributing to the failure of separation between steel and concrete. Values of corroded members are lower compared to coated members. The results showed that the resins / exudates strengthen the reinforcement and act as a protective coat against corrosion.

[11] Investigated on the application of the invingia gabonensis exudates / resin to reinforcing steel of varying thicknesses embedded in concrete cubes and partially pooled in corrosive media. Relatively, corroded models showed lower failure load and high yield on low load application. Exudates / resins coated models exhibit corrosion resistant properties, which have a low failure load, high bonding, and maximum slip strength on depleted specimens.

[12] Introduced coated reinforced steel of varying thicknesses with exudates/resins, aimed at reducing the corrosion effect and attack on reinforcing steel embedded in concrete structures (beam) and exposed to corrosive media and investigated the impact of corrosion on concrete beam on coated and non-coated members. Extensive test results have shown potential corrosion resistance with coating members on mechanical properties that strengthen the effects of weight loss, cracking, spalling and weight loss. Experimental results showed signs of corrosion on non-coated reinforcing member which resulted to surface modification, reduction in cross-sectional area, weight loss and cracking appearance. Evaluated computed comparative results showed low load application to high yield effects, high deflected midspan and elongation over coated and controlled samples.

[13] Evaluated the effectiveness of the use of steel reinforcing olibanum exudates/resins embedded in concrete and immersed in a corrosive medium for the potential of corrosion through the embedded concrete members of the coated and non-coated members were first monitored for cracking and dispersion. Corroded members show lower flexural loads to decreased values resulting from the effect of corrosion attacks, reduction in cross-sectional area and weight loss effects.

[14] Studied the effectiveness of naturally occurring products of Garcinia Cola extracts (exudates/resins) as a protective membrane for reinforcing steel embedded in concrete. Members were immersed in severe corrosive conditions and accelerated for 150 days with experiments on changes in the mechanical properties of the steel. Indications have shown that 
non-coated samples exhibited corrosion properties that resulted to surface modification and negative effect on the general mechanical properties of reinforcing steel. Uncoated ( corroded) member results have higher values of elastic failure load, lower midspan deflection and yield strength, strain rate, and extension than all coated members

[15] Examined surface modifications, diameter reduction, and weight reduction of reinforcing steel of non-coated and exudates/resins coating members in an aggressive environment. The coated members of different thicknesses were embedded in concrete structures, exposed, and monitored over 150 days. Due to corrosion, steel showed lower results in strengthening mechanical properties, resulting in lower yields, higher midspan deflection, and extension, while coated members maintained greater structural integrity. The coated members showed greater flexibility before failure.

[16] Investigated the effect of reinforcing steel by introducing milicia excelsa exudates/resins for surface modification and reducing steel in concrete structures. The corrosion acceleration process was 150 days and corrosion efficiency was determined. Overall, experimental results have shown that spills and fracture corrosion properties in coating members represent a low flexibility failure load; the effect of corrosion on the mechanical properties of reinforcing steel over the degraded (controlled) members has not been watched. Midspan deflection, extension, and ultimate yield, high flexibility failure load required and compared to corroded members.

[17] Investigated the comparative effect of reinforcing steel coated with Khaya senegalensis exudates/resins and non-coated members on the residual flexural strength after 150 days of corrosion fast periods. Decreased members overestimated overall outcomes; Flexural failure loads against corrugated and uncoated models, midspan deflection against corrugated and uncoated specimens, and ultimate tensile strength of corrugated and uncoated specimens. Corrosion attack on mechanical properties of reinforcing steel embedded in concrete has led to the behavior of the tested properties.

[18] Examined the potential application of resin extract of inorganic resistant natural exudates grewia. The results showed a high ultimate yield of corrugated specimens to control and coating specimens due to the effect of corrosion on the mechanical properties of steel reinforcement. The results of the weight loss of steel showed a high percentage of values against the control and coating models due to the effect of corrosion on the mechanical properties.

\section{MATERIALS AND METHODS FOR EXPERINMENT}

\section{Aggregates}

Fine and coarse collections were purchased. Both meet the requirements of [19]

\section{Cement}

Limestone Cement Grade 42.5 is the most common type of cement in the Nigerian market. It was used for all concrete mixes in this test. Cement meets the requirements of [20]

\section{Water}

The water samples were clean and free of impurities. The freshwater used was obtained from Civil Engineering Laboratory, Kenule Beeson Saro-Wiwa Polytechnic, Bori, Rivers State. Water meets the requirements of [21]

\section{Structural Steel Reinforcement}

Reinforcements are obtained directly from the market at Port Harcourt. Confirmed on [22]

\section{Corrosion Inhibitors (Resins / Exudates) Boswellia dalzielii (Burseraceae)}

The natural gum exudates were obtained from the tree bark by tapping in Isanlu Isin or Isanlusin is an ancient town in Isin LGA of Kwara State, Nigeria. Isin LGA of Kwara State 


\section{Methods}

This research evaluated the application of exudates/resins from naturally occurring plant extrudes with environmentally friendly characteristics of non-harmful materials obtained from tree trunks. The viscous exudate/resin was embedded in the concrete beam after coating of varying thicknesses and was applied directly to the steel reinforcement and evaluating its usefulness as corrosion-resistant to structures exposed to the harsh and severe environment of the coastal marine.

The purpose of this study is to use materials that are widely available locally to prevent the negative effect of corrosion attacks on steel reinforcement in the highest salt concentration (sodium chloride) of the marine environment. Beam samples of $175 \mathrm{~mm} \times 175 \mathrm{~mm} 750 \mathrm{~mm}$, thickness, width, and length, with four (4) numbers with a diameter of $16 \mathrm{~mm}$ were embedded into the beams and immersed wholly submerged in sodium chloride $(\mathrm{NaCl})$ for 360 days after the initial 28 days of curing. Corrosion is a long-term natural occurring process that spanned many years to manifest, but the artificial introduction of sodium chloride $(\mathrm{NaCl})$ accelerates and stimulates the corrosion rate that represents the coastal region salt concentration, and this process is soon achieved with the shortest time. The study further aims to determine the role of the exudate/resin against adverse attacks on the reinforcement by its waterproofing and resistance (resistance) and the improvement of the reinforcement surface of the steel due to coating application.

\section{Sample preparation and casting of solid beams}

The standard method of concrete mixing ratio was followed, manual manipulation by material weight. The mix ratio of concrete is $1: 2: 4$, the water-cement ratio is 0.65 . Manual mixing was applied to clean concrete edges, and the mixing was inspected and water was slowly added to obtain a complete mixing design concrete. Continuous uniform color and consistency were achieved by adding cement, water, and aggregate. The test beams were cast in a steel mold of $175 \mathrm{~mm} \times 175 \mathrm{~mm} \times 750 \mathrm{~mm}$ and were fitted with inlet air and $16 \mathrm{~mm}$ diameter reinforcing steel 4 numbers were embedded. Samples were de-molded after 72 hours and cured for 28 days in standard procedures and at room temperature in pooling tanks for rapid corrosion acceleration testing process for 360 days at 3 months interval testing of 90 days, 180 days, 270 days, and 360 days, and observations were first to crack appearance Performed on.

\section{Flexural Testing of Beam specimens}

According to [25], the Universal Testing Machine was used for flexural testing and a total of 36 beam models were tested. After 28 initial and standard cures of treatment, 12 beams (noncoated) were kept under control to prevent corrosion-related reinforcement, while 24 beam samples of non-coated and exudate/resin coated samples were completely immersed in 5\% sodium chloride (surface) $\mathrm{NaCl}$ for 360 days with regular testing at 90 days, 180 days, 270 days and 360 days and examining the effects of changes in mechanical properties for both non-coated (corroded) and coated samples). Flexural testing was performed on an Intron Universal testing machine with a capacity of $100 \mathrm{KN}$. Samples were placed on the specification in the machine, and flexural testing was performed on two supports in the third stage. Cracks and flexural strength load by digitally recorded and computerized system, midspan deflection, and all corresponding investigations of measured rebar diameter before the test, rebar diameter- after corrosion, cross-sectional area reduction/increase, yield strength, ultimate tensile strength, strain ratio, elongation, rebar weights- before the test, rebar weights- after corrosion, and weight loss /gain of steel were all observed and recorded. 
DOI : https://dx.doi.org/10.26808/rs.ed.i11v5.01

International Journal of Emerging Trends in Engineering and Development

Issue 11, Vol.5 (Aug-Sep 2021)

Available online on http://www.rspublication.com/ijeted/ijeted_index.htm

ISSN 2249-6149

\section{Table 3.1 : Flexural Strength of Beam Specimens (Controlled}

\begin{tabular}{|c|c|c|c|c|c|c|c|c|c|c|c|c|}
\hline Samples & \multicolumn{3}{|c|}{ Samples A } & \multicolumn{3}{|c|}{ Samples B } & \multicolumn{3}{|c|}{ Samples C } & \multicolumn{3}{|c|}{ Samples D } \\
\hline Iterms & BA & BA1 & BA2 & BA3 & BA4 & BA5 & BA6 & BA7 & BA8 & BA9 & BA10 & BA11 \\
\hline $\begin{array}{l}\text { Flexure Load } \\
(\mathrm{KN})\end{array}$ & 80.52 & 84.09 & 84.21 & 85.52 & 83.56 & 85.07 & 83.12 & 84.82 & 84.14 & 85.67 & 85.52 & 85.00 \\
\hline $\begin{array}{c}\text { Midspan } \\
\text { Deflection }(\mathrm{mm})\end{array}$ & 6.08 & 5.32 & 5.92 & 6.03 & 5.12 & 6.06 & 5.15 & 5.32 & 5.12 & 5.20 & 5.20 & 6.05 \\
\hline $\begin{array}{c}\text { Nominal Bar } \\
\text { Diameter }(\mathrm{mm})\end{array}$ & 16.00 & 16.00 & 16.00 & 16.00 & 16.00 & 16.00 & 16.00 & 16.00 & 16.00 & 16.00 & 16.00 & 16.00 \\
\hline $\begin{array}{c}\text { Measured Rebar } \\
\text { Diameter Before } \\
\text { Test }(\mathrm{mm})\end{array}$ & 15.98 & 15.99 & 15.99 & 15.98 & 15.99 & 15.97 & 15.98 & 15.98 & 15.96 & 15.99 & 15.98 & 15.99 \\
\hline $\begin{array}{c}\text { Rebar Diamete at } \\
28 \text { days }(\mathrm{mm})\end{array}$ & 15.98 & 15.99 & 15.99 & 15.98 & 15.99 & 15.97 & 15.98 & 15.98 & 15.96 & 15.99 & 15.98 & 15.99 \\
\hline $\begin{array}{c}\text { Cross- section } \\
\text { Area } \\
\text { Reduction/Increase } \\
\text { ( Diameter, mm) }\end{array}$ & 0.00 & 0.00 & 0.00 & 0.00 & 0.00 & 0.00 & 0.00 & 0.00 & 0 & 0.00 & 0.00 & 0.00 \\
\hline $\begin{array}{l}\text { Yield Strength, fy } \\
(\mathrm{MPa})\end{array}$ & 458.38 & 455.18 & 454.08 & 453.90 & 453.63 & 453.70 & 453.59 & 454.11 & 454.04 & 451.82 & 454.31 & 454.22 \\
\hline $\begin{array}{c}\text { Ultimate Tensile } \\
\text { Strength, fu (MPa) }\end{array}$ & 600.40 & 595.35 & 597.03 & 592.81 & 596.34 & 596.76 & 596.56 & 597.36 & 595.96 & 598.51 & 601.01 & 599.87 \\
\hline Strain Ratio & 1.31 & 1.31 & 1.32 & 1.31 & 1.32 & 1.32 & 1.32 & 1.32 & 1.31 & 1.33 & 1.32 & 1.32 \\
\hline Elongation (\%) & 9.15 & 8.85 & 8.92 & 9.05 & 8.25 & 9.05 & 9.39 & 7.85 & 8.42 & 8.35 & 8.95 & 8.89 \\
\hline $\begin{array}{l}\text { Rebar Weights- } \\
\text { Before Test }\end{array}$ & 1.76 & 1.77 & 1.78 & 1.76 & 1.77 & 1.71 & 1.76 & 1.77 & 1.74 & 1.78 & 1.76 & 1.77 \\
\hline $\begin{array}{c}\text { Rebar Weights- } \\
\text { After at } 28 \text { days } \\
(\mathrm{Kg})\end{array}$ & 1.76 & 1.77 & 1.78 & 1.76 & 1.77 & 1.71 & 1.76 & 1.77 & 1.74 & 1.78 & 1.76 & 1.77 \\
\hline $\begin{array}{c}\text { Weight Loss /Gain } \\
\text { of Steel }(\mathrm{Kg}) \text { at } 28 \\
\text { days }\end{array}$ & 0.00 & 0.00 & 0.00 & 0.00 & 0.00 & 0.00 & 0.00 & 0.00 & 0.00 & 0.00 & 0.00 & 0.00 \\
\hline
\end{tabular}

Table 3.2 : Flexural Strength of Beam Specimen (Corroded specimens)

\begin{tabular}{|c|c|c|c|c|c|c|c|c|c|c|c|c|}
\hline & BA1A & BA1B & BA1C & BA1D & BA1E & BA1F & BA1G & BA1H & BA1I & BA1J & BA1K & BA1L \\
\hline Flexure Load (KN) & 62.79 & 67.15 & 66.49 & 65.86 & 65.84 & 66.28 & 65.39 & 67.10 & 66.42 & 67.35 & 67.30 & 67.80 \\
\hline $\begin{array}{l}\text { Midspan Deflection } \\
(\mathrm{mm})\end{array}$ & 14.47 & 14.60 & 13.72 & 14.32 & 14.43 & 13.52 & 14.46 & 13.55 & 13.72 & 13.52 & 13.60 & 13.60 \\
\hline Nominal Rebar Diameter & 16.00 & 16.00 & 16.00 & 16.00 & 16.00 & 16.00 & 16.00 & 16.00 & 16.00 & 16.00 & 16.00 & 16.00 \\
\hline $\begin{array}{c}\text { Measured Rebar } \\
\text { Diameter Before } \\
\text { Test }(\mathrm{mm})\end{array}$ & 15.98 & 15.99 & 15.99 & 15.98 & 15.99 & 15.97 & 15.98 & 15.98 & 15.96 & 15.99 & 15.98 & 15.99 \\
\hline $\begin{array}{l}\text { Rebar Diameter- After } \\
\text { Corrosion }(\mathrm{mm})\end{array}$ & 15.94 & 15.93 & 15.91 & 15.93 & 15.94 & 15.92 & 15.93 & 15.93 & 15.94 & 15.94 & 15.93 & 15.94 \\
\hline $\begin{array}{l}\text { Cross- section Area } \\
\text { Reduction/Increase ( } \\
\text { Diameter, mm) }\end{array}$ & 0.04 & 0.06 & 0.08 & 0.05 & 0.05 & 0.05 & 0.05 & 0.05 & 0.03 & 0.05 & 0.05 & 0.05 \\
\hline Yield Strength, fy (MPa) & 431.52 & 428.32 & 427.22 & 427.04 & 426.77 & 426.84 & 426.73 & 427.25 & 427.18 & 424.96 & 427.45 & 427.36 \\
\hline $\begin{array}{c}\text { Ultimate Tensile } \\
\text { Strength, fu (MPa) }\end{array}$ & 580.92 & 575.87 & 577.55 & 573.33 & 576.86 & 577.28 & 577.08 & 577.88 & 576.48 & 579.03 & 581.53 & 580.39 \\
\hline Strain Ratio & 1.35 & 1.34 & 1.35 & 1.34 & 1.35 & 1.35 & 1.35 & 1.35 & 1.35 & 1.36 & 1.36 & 1.36 \\
\hline Elongation (\%) & 19.04 & 18.74 & 18.81 & 18.94 & 18.14 & 18.94 & 19.28 & 17.74 & 18.31 & 18.24 & 18.84 & 18.78 \\
\hline $\begin{array}{c}\text { Rebar Weights- Before } \\
\text { Test }(\mathrm{Kg})\end{array}$ & 1.76 & 1.77 & 1.78 & 1.76 & 1.77 & 1.71 & 1.76 & 1.77 & 1.74 & 1.78 & 1.76 & 1.77 \\
\hline $\begin{array}{l}\text { Rebar Weights- After } \\
\text { Corrosion }(\mathrm{Kg})\end{array}$ & 1.72 & 1.72 & 1.73 & 1.72 & 1.72 & 1.66 & 1.72 & 1.73 & 1.70 & 1.74 & 1.72 & 1.73 \\
\hline $\begin{array}{l}\text { Weight Loss /Gain of } \\
\text { Steel }(\mathrm{Kg})\end{array}$ & 0.04 & 0.04 & 0.04 & 0.04 & 0.04 & 0.04 & 0.04 & 0.04 & 0.04 & 0.04 & 0.04 & 0.04 \\
\hline
\end{tabular}


DOI : https://dx.doi.org/10.26808/rs.ed.i11v5.01

International Journal of Emerging Trends in Engineering and Development

Issue 11, Vol.5 (Aug-Sep 2021)

Available online on http://www.rspublication.com/ijeted/ijeted_index.htm

ISSN 2249-6149

Table 3.3: Flexural Strength of Boswellia dalzielii (Burseraceae) Exudate / resin Coated Beam Specimens

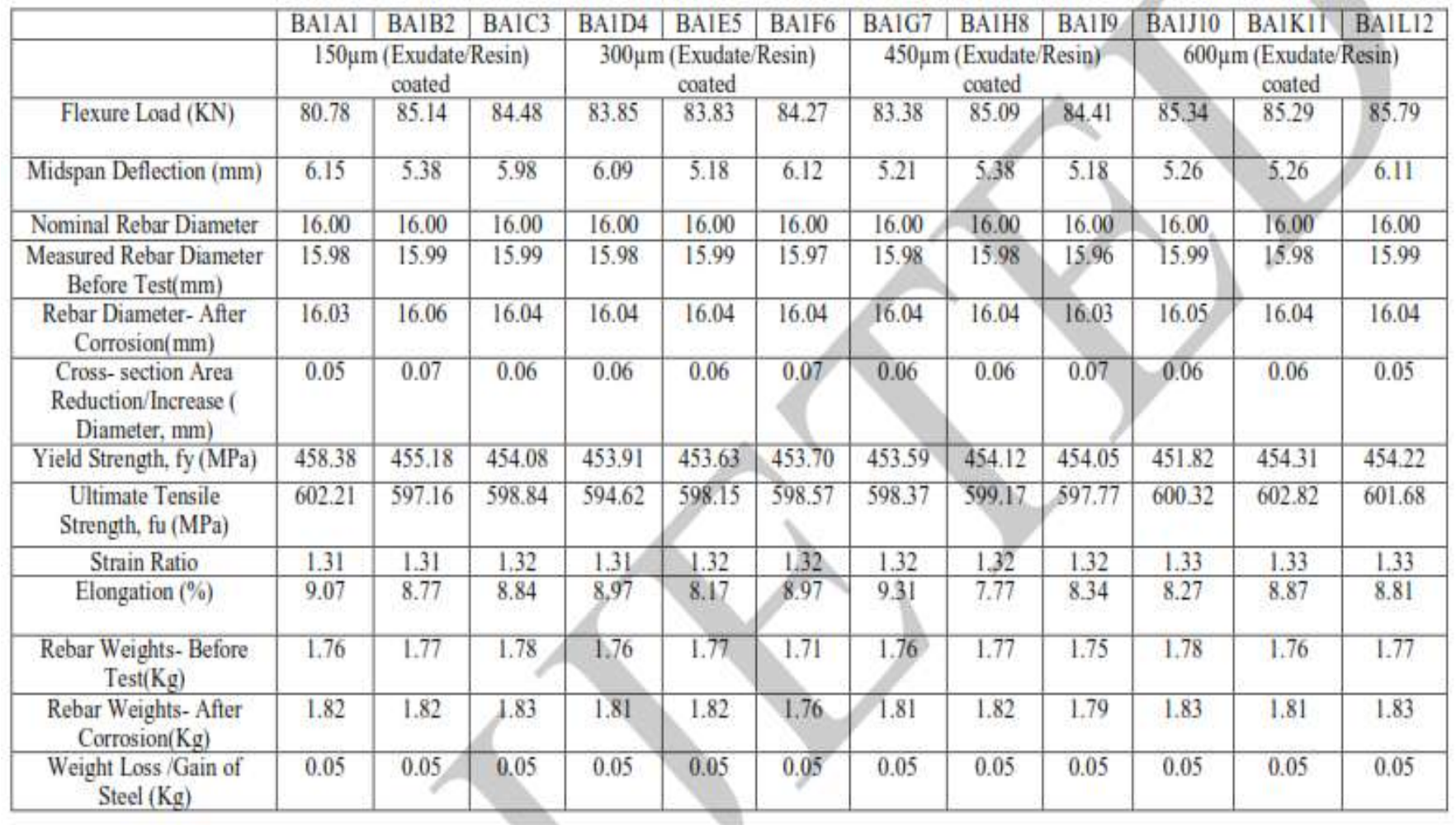

Table 3. 4 : Average Flexural Strength of Beam Specimens (Control, Corroded and Exudate/Resin Coated (specimens)

\begin{tabular}{|c|c|c|c|c|c|c|c|c|c|c|c|c|}
\hline \multirow[b]{2}{*}{ Flexure Load (KN) } & \multicolumn{4}{|c|}{$\begin{array}{l}\text { Average Flexural Strength of } \\
\text { Control Beam Specimens }\end{array}$} & \multicolumn{4}{|c|}{$\begin{array}{l}\text { Average Flexural Strength of } \\
\text { Corroded Beam Specimens }\end{array}$} & \multicolumn{4}{|c|}{$\begin{array}{l}\text { Average Flexural Strength of } \\
\text { Boswellia dalzielili (Burseraceae) } \\
\text { Exudate/Resin Coated Beam }\end{array}$} \\
\hline & 82.94 & 84.72 & 84.03 & 85.40 & 65.48 & 65.99 & 66.30 & 67,48 & 83.46 & 83.98 & 84.29 & 85.47 \\
\hline Midspan Deflection (mm) & 6.77 & 5.73 & 5.19 & 5.48 & 14.27 & 14.09 & 13.91 & 13.58 & 6.84 & 5.80 & 5.26 & 5.55 \\
\hline Nominal Rebar Diameter & 16.00 & 16.00 & 16.00 & 16.00 & 16.00 & 16.00 & 16.00 & 16.00 & 16.00 & 16.00 & 16.00 & 16.00 \\
\hline $\begin{array}{l}\text { Measured Rebar Diameter } \\
\text { Before Test(mm) }\end{array}$ & 15.99 & 15.98 & 15.97 & 15.99 & 15.99 & 15.98 & 15.97 & 15.99 & 15.99 & 15.98 & 15.97 & 15.99 \\
\hline $\begin{array}{l}\text { Rebar Diameter-After } \\
\text { Corrosion }(\mathrm{mm})\end{array}$ & 15.99 & 15.98 & 15.97 & 15.99 & 15.93 & 15.93 & 15,93 & 15.94 & 16.04 & 16.04 & 16.03 & 16.04 \\
\hline $\begin{array}{l}\text { Cross- section Area } \\
\text { Reduction/Increase ( } \\
\text { Diameter, mm) }\end{array}$ & 0.00 & 0.00 & 0.00 & 0.00 & -0.06 & -0.05 & -0.04 & -0.05 & 0.06 & 0.06 & 0.06 & 0.05 \\
\hline Yield Strength, fy (MPa) & 455.88 & 453,74 & 45391 & 453.45 & 429.02 & 426.88 & 427.05 & 426.59 & 455.88 & 453.75 & 453.92 & 453.45 \\
\hline $\begin{array}{l}\text { Ultimate Tensile Strength, } \\
\text { fu (MPa) }\end{array}$ & 597.60 & 595.31 & 596.63 & 599.80 & 578.11 & 575.82 & 577.15 & 580.32 & 599.40 & 597.11 & 598.43 & 601.60 \\
\hline Strain Ratio & 1,31 & 1.31 & 1.31 & 1.32 & 1.35 & 1.35 & 1.35 & 1.36 & 1.32 & 1.32 & 1.32 & 1.33 \\
\hline Elongation (\%) & 8.97 & 8.78 & 8.55 & 8.73 & 18.86 & 18.67 & 18.44 & 18.62 & 8.90 & 8.71 & 8.48 & 8.65 \\
\hline $\begin{array}{l}\text { Rebar Weights- Before } \\
\text { Test }(\mathrm{Kg})\end{array}$ & 1.77 & 1.74 & 1.76 & 1.77 & 1.77 & 1.74 & 1.76 & 1.77 & 1.77 & 1.74 & 1.76 & 1.77 \\
\hline $\begin{array}{l}\text { Rebar Weights-After } \\
\text { Corrosion }(\mathrm{Kg})\end{array}$ & 1.77 & 1.74 & 1.76 & 4.77 & 1.73 & 1.70 & 1.7 & 1.73 & 1.82 & 1.80 & 1.81 & 1.82 \\
\hline $\begin{array}{l}\text { Weight Loss /Gain of Steel } \\
(\mathrm{Kg})\end{array}$ & 0.00 & 0.00 & 0.00 & 0.00 & 0.04 & 0.04 & 0.04 & 0.04 & 0.05 & 0.05 & 0.05 & 0.05 \\
\hline
\end{tabular}


DOI : https://dx.doi.org/10.26808/rs.ed.i11v5.01

International Journal of Emerging Trends in Engineering and Development

Issue 11, Vol.5 (Aug-Sep 2021)

Available online on http://www.rspublication.com/ijeted/ijeted_index.htm

ISSN 2249-6149

Table 3.5: Average Percentile Flexural Strength of Beam Specimens (Control, Corroded and Exudates Coated (specimens)

\begin{tabular}{|c|c|c|c|c|c|c|c|c|c|c|c|c|}
\hline & \multicolumn{4}{|c|}{$\begin{array}{l}\text { Average Percentile Flexural Strength } \\
\text { of Control Beam Specimens }\end{array}$} & \multicolumn{4}{|c|}{$\begin{array}{c}\text { Average Percentile Flexural } \\
\text { Strength of Corroded Beam } \\
\text { Specimens }\end{array}$} & \multicolumn{4}{|c|}{$\begin{array}{l}\text { Average Percentile Flexural Strength of } \\
\text { Boswellia dalzielii (Burseraceae) } \\
\text { Exudate/Resin Coated Beam Specimens }\end{array}$} \\
\hline Flexure Load $(\mathrm{KN})$ & 26.67 & 28.38 & 26.73 & 26.55 & -21.55 & -21.42 & -21.34 & -21.04 & 27.47 & 27.25 & 27.13 & 26.65 \\
\hline Midspan Deflection (mm) & -52.53 & -59.33 & -62.68 & -59.65 & 108.52 & 142.94 & 164.46 & 144.70 & -52.04 & -58.84 & -62.19 & -59.13 \\
\hline Nominal Rebar Diameter & 0.00 & 0.00 & 0.00 & 0.00 & 0.00 & 0.00 & 0.00 & 0.00 & 0.00 & 0.00 & 0.00 & 0.00 \\
\hline $\begin{array}{l}\text { Measured Rebar Diameter } \\
\text { Before Test(mm) }\end{array}$ & 0.354 & 0.356 & 0.358 & 0.354 & 0.355 & 0.371 & 0.359 & 0.368 & 0.379 & 0.373 & 0.372 & 0.355 \\
\hline $\begin{array}{l}\text { Rebar Diameter-After } \\
\text { Corrosion(mm) }\end{array}$ & 0.37 & 0.31 & 0.26 & 0.31 & -0.73 & -0.69 & -0.63 & -0.64 & 0.74 & 0.69 & 0.63 & 0.65 \\
\hline $\begin{array}{l}\text { Cross- section Area } \\
\text { Reduction/Increase ( } \\
\text { Diameter, mm) }\end{array}$ & 0.00 & 0.00 & 0.00 & 0.00 & 1.72 & -16.67 & -32.79 & 5.66 & -1.70 & 20.00 & 48.78 & 6.00 \\
\hline Yield Strength, fy (MPa) & 6.26 & 6.29 & 6.29 & 6.30 & -5.89 & -5.92 & $-5,92$ & -5.93 & 6.26 & 6.29 & 6.29 & 6.30 \\
\hline $\begin{array}{l}\text { Ultimate Tensile Strength, } \\
\text { fu (MPa) }\end{array}$ & 3.37 & 3.38 & 3.38 & 3.36 & -3.55 & -3.57 & -3.56 & -3.54 & 3.68 & 3 & 3.69 & 3.67 \\
\hline Strain Ratio & -2.75 & -2.74 & -2.74 & -2.72 & 2.51 & 2.51 & 2.50 & 2.49 & -2.45 & -2.45 & -2.44 & -2.43 \\
\hline Elongation (\%) & -13.03 & -13.28 & -12.92 & -12.98 & 20.62 & 20.35 & 20.27 & 20.43 & -23.89 & -23.88 & -23.82 & -23.99 \\
\hline $\begin{array}{c}\text { Rebar Weights- Before } \\
\text { Test }(\mathrm{Kg})\end{array}$ & 0.063 & 0.0678 & 0.068 & 0.064 & 0.065 & 0.066 & 0.066 & 0.064 & 0.066 & 0.065 & 0.066 & 0.067 \\
\hline $\begin{array}{l}\text { Rebar Weights-After } \\
\text { Corrosion }(\mathrm{Kg})\end{array}$ & 2.49 & 2.47 & 2.45 & 2.49 & -5.27 & -5.29 & -5.25 & -5.26 & 5.56 & 5.59 & 5.54 & 5.56 \\
\hline $\begin{array}{l}\text { Weight Loss / Gain of Steel } \\
(\mathrm{Kg})\end{array}$ & 0.00 & 0.00 & 0.00 & 0.00 & -20.76 & -20.76 & -14.29 & -20.76 & 26.19 & 26.19 & 16.67 & 26.19 \\
\hline
\end{tabular}

\section{EXPERIMENTAL RESULTS AND DISCUSSION}

\section{Results and Discussion of Concrete Beam Members Flexural Strength Load and Midspan Deflection}

Corrosion of reinforced concrete or concrete has led to the sudden collapse of many of the exposed structures in coastal areas with severe weather. The effect of corrosion on flexural forces has been investigated by a large number of investigators and is well understood. Many studies conducted in this area have been described by critical tests of their effectiveness in the effects of corrosion on the flexibility of reinforced concrete beams.

Considering the effect of corrosion on reinforced concrete structures built within the coastal areas of Niger Delta, Nigeria, with high salinity, the application of Boswellia dalzielii (Burseraceae) exudates/resin extracts of tree sources with eco-friendly was introduced, applied directly to embedded reinforcing steel in concrete beams and assessed its effectiveness as an inhibitory substance against corrosion.

Corrosion of reinforced steel leads to a reduction in the cross-sectional area of the steel bar and the accumulation of corrosion products, which in turn reduces the ductility and strength of the steel. Corrosion products occupy a volume 2 to 6 times greater than that of the original reinforced steel [23]. The initial corrosion products around the surface of the steel bar cause longitudinal cracking, hatching, and delamination of the concrete shell. The loss of the concrete layer, in turn, leads to the loss of enclosed space by reducing the strength of the joints in the intermediate zone between the steel rails and the concrete.

Experimental data for flexural tests on concrete girder samples are shown in Tables 3.1, 3.2, and 3.3, summarized in 3.4, mean and percentile values in 3.5, and the results are shown graphically in Figures $3.1-3.7 \mathrm{~b}$. The average value and the minimum and maximum percentage calculated are the flexural strength of the Instron Universal Testing Machine with a compression of $100 \mathrm{kN}$ under pressure until the failure state is a controlled sample of $82.94 \mathrm{kN}$ and $85.4 \mathrm{kN}$ (26.55\% and $28.38 \%$ ), the corrosion values of the samples were 
$65.48 \mathrm{kN}$ and $67.48 \mathrm{kN}(-21.55 \%$ and $-21.04 \%)$, and the samples coated with exudates/resin were $83.46 \mathrm{kN}$ and $85.47 \mathrm{kN}(26.65 \%$ and $27.47 \%)$.

From the flexural strength test, the maximum value was $28.38 \%$ compared to the corroded and coated sample values of $-21.04 \%$ and $27.47 \%$, respectively. The mean differential and percentile ranges were examined $(2.46 \mathrm{kN}$ and $1.83 \%)$, corroded $(2.05 \mathrm{kN}$ and $0.51 \%)$, coated $(2.01 \mathrm{kN}$ and $0.82 \%)$. The results show that the reference percentage of the controlled sample was placed in freshwater according to BS 3148 and no corrosion effect was observed and was therefore used as a reference value for uncoated and coated in a corrosive environment as described in the test program. Corroded specimens fail with a lower load, whereas coated specimens have a higher load if the failure occurs. The results further confirm that the flexural stress-strain of controlled and coated specimens maintains a within range of values over the corroded specimens at moderate, reduced, and lower loads.

The results of minimum and maximum average and percentile midspan deflection failure loads recorded of non-coated are $5.19 \mathrm{kN}$ and $6.77 \mathrm{kN}(-62.68 \%$ and $-52.53 \%)$, corroded samples are $13.58 \mathrm{kN}$ and $14.27 \mathrm{kN}(62.52 \%$ and $74.46 \%)$ and the coated samples are $5.26 \mathrm{kN}$ and $6.84 \mathrm{kN}(-62.19 \%$ and $-52.04 \%)$. The comparative midspan deflection results showed that the maximum obtained values to the failure state are controlled $-52.53 \%$ against corroded $74.46 \%$ and coated $-52.04 \%$. The average and percentile differential values recorded are controlled $(1.58 \mathrm{kN}$ and $10.15 \%)$, corroded $(0.69 \mathrm{kN}$ and $5.94 \%)$, and coated are $(1.58 \mathrm{kN}$ and $10.15 \%$ ). The results showed a lower elongation load in the case of controlled and coated samples with a reduction value above the corrosion samples with higher elongation loads and increased values compared to the reference range (controlled) and coated samples. The evaluation results obtained for the flexural strength and deformation load in the center of the corroded sample show the effect of corrosion on the mechanical properties of reinforcing steel with detached ribs, high surface modification, which causes low load-carrying capacity, and high deformation in the midspan with the works ([18], [15],[10], [12] and [16]). From the results obtained, the exudates/resin of Boswellia dalzielii (Burseraceae) has proven to be a corrosion protection agent in reinforced concrete structures exposed to a corrosive environment, with high resistance and as an insulating membrane against the effects of corrosion.

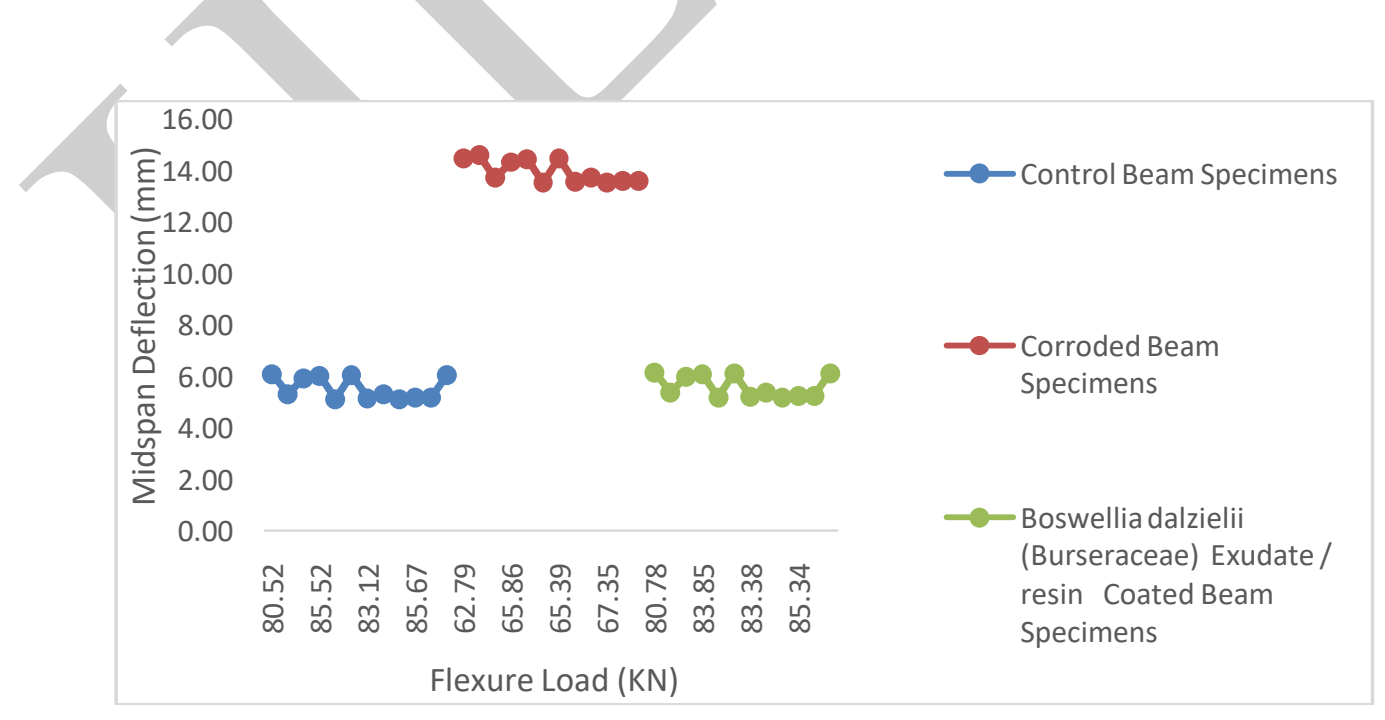

Figure 3.1: Failure Load versus Midspan Deflection of Beam Specimens (Non-Corroded, Corrode and Resin Coated Specimens 


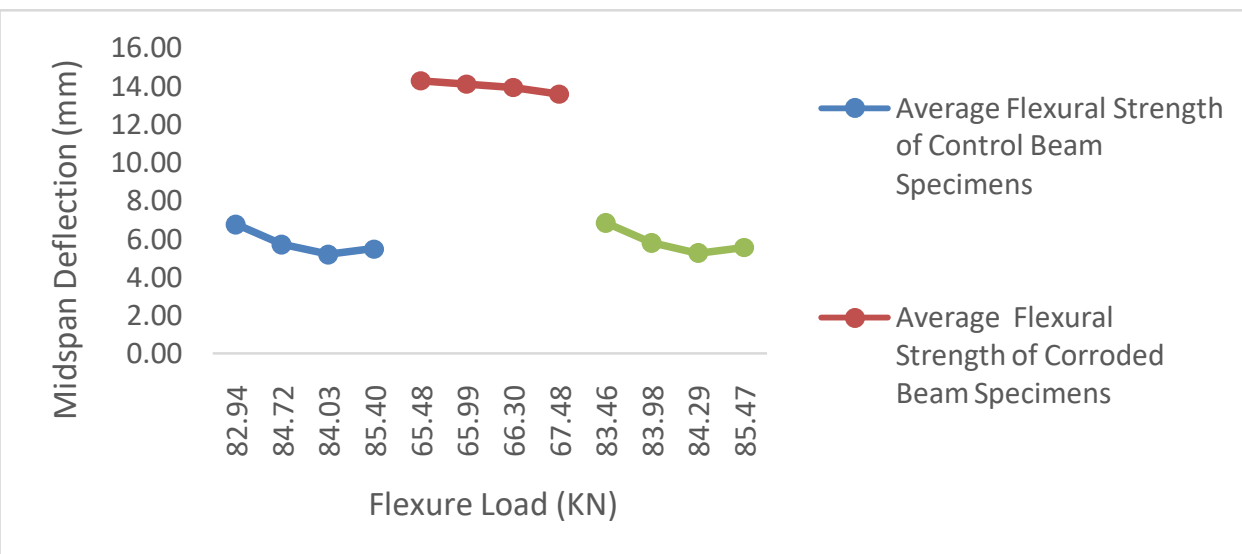

Figure 3.1A: Average Failure Load versus Midspan Deflection of Beam Specimens (Non-Corroded, Corrode and Resin Coated Specimens

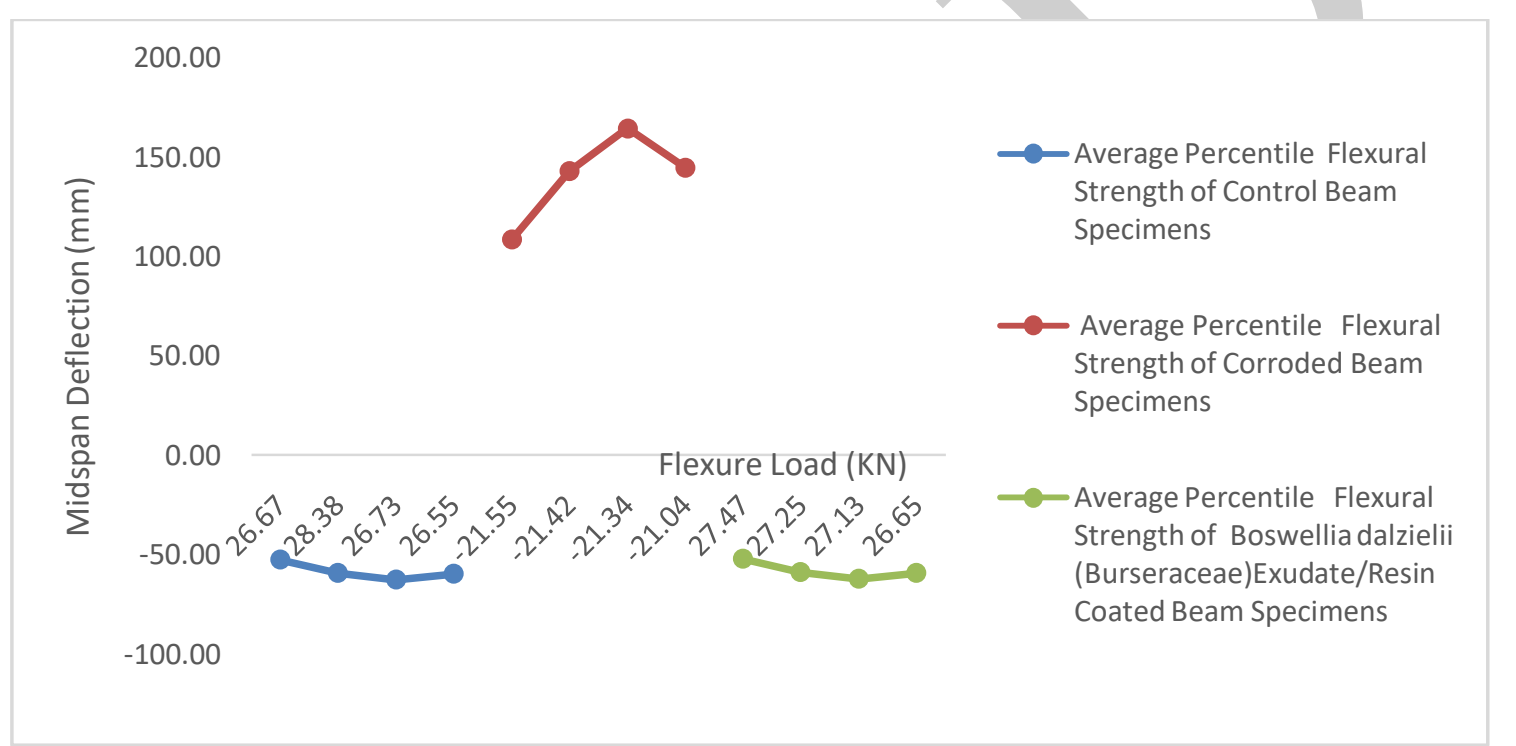

Figure 3.1B: Average Percentile Failure Load versus Midspan Deflection of Beam Specimens (Non-Corroded, Corrode and Resin Coated Specimens

\section{Results of Measured Rebar Diameter Before and After Corrosion Test}

The decrease in the flexibility of corroded concrete beams is precisely determined taking into account the loss of the cross-section of the reinforcement, which causes a decrease in strength and a decrease in the strength of the joint due to corrosion of the reinforcement. Steel corrosion in reinforced concrete structures causes loss of reinforcement area and damage to the surrounding concrete. This increases deformation, crack width, and stress, as well as a reduction in load-carrying capacity. Corrosion of steel causes a reduction in the area of reinforcement, changes in the mechanical properties of reinforcement ${ }^{[27]}$, cracks and delamination of the concrete cover, and a reduction in the contact area between the reinforcement and the surrounding concrete. The results obtained from the minimum and maximum mean and percentage values for the nominal valve size are $16 \mathrm{~mm}(100 \%)$ for all standards. Reinforcement diameters measured before testing for controlled samples were $15.97 \mathrm{~mm}$ and $15.99 \mathrm{~mm}(0.354 \%$ and $0.358 \%)$, the corroded $15.97 \mathrm{~mm}$ and $15.97 \mathrm{~mm}$ $(0.33 \%$ and $0.39 \%)$ and coated $15.98 \mathrm{~mm}$ and $15.99 \mathrm{~mm}(0.34 \%$ and $0.38 \%)$. The results obtained indicate that the diameter of the reinforcing steel fluctuates due to the manufacture 
of reinforcement by different companies; production mold used has caused the average value and the percentage difference to be insignificant.

The average values and the minimum and maximum percentages of the rebar diameter - after the controlled corrosion test were 115.93 and $15.93 \mathrm{~mm}(0.63 \%$ and $0.69 \%)$, the corroded sample values were $15.88 \mathrm{~mm}$ and $15.91 \mathrm{~mm}(-1.10 \%$ and $-0.91 \%)$, the values of the coated samples were $16.05 \mathrm{~mm}$ and $16.06 \mathrm{~mm}(1.1 \%$ and $1.21 \%)$.

The comparison results obtained during and after the corrosion test the maximum value of the diameter of the anchor checked was $0.69 \%$ compared to the corroded one at $-0.91 \%$ and the sample with a coating of $1.11 \%$. The calculated mean differential and percentile values were checked $(0.02 \mathrm{kN}$ and $0.11 \%)$, corroded values were $(0.013 \mathrm{kN}$ and $0.1 \%)$, and coated values $(0.01 \mathrm{kN}$ and $0.11 \%)$. The results showed that the effect of corrosion on the mechanical properties of reinforcing steel with a decrease in diameter reduced the average and percentage of samples corroded, while the controlled and coated samples showed a preserved state due to coating due to an increase in diameter different layer thicknesses with exudate/resin. The use of exudates/resin protects the reinforcing steel from severe corrosion damage. The mean and percentile values determined after and before the corrosion test harm the diameter of the reinforcing steel, which leads to a reduction and an increase in the cross-sectional area.

The minimum and maximum obtained "decrease/increase in cross-sectional area (diameter)" of the controlled sample is $0.00 \mathrm{~mm}$, which shows $(100 \%)$ for all samples, samples corroded $0.066 \mathrm{~mm}$ and $-0.04 \mathrm{~mm}, 79 \%$ and $10.72 \%$ ) and coated samples were $0.05 \mathrm{~mm}$ and $0.06 \mathrm{~mm}$ $(12.35 \%$ and $18.49 \%)$.

The cross-sectional area of reinforcing steel gives different mean and percentile values for corroded values $(0.02 \mathrm{~mm}$ and $4.51 \%)$ and coated values $(0.01 \mathrm{~mm}$ and $9.18 \%)$.

The results obtained showed the effect of corrosion on the mechanical properties of reinforcing steel with a decrease in the diameter of the reinforcement in the corroded sample, while the coated sample showed an increase due to the thickness of the exudates paste layer. The reduction in cross-sectional area is due to the corrosive effect on reinforced concrete structures constructed in marine coastal environments and the increased protective layer by work-related exudates/resins ([12], [14], [10], [12] and [16]).

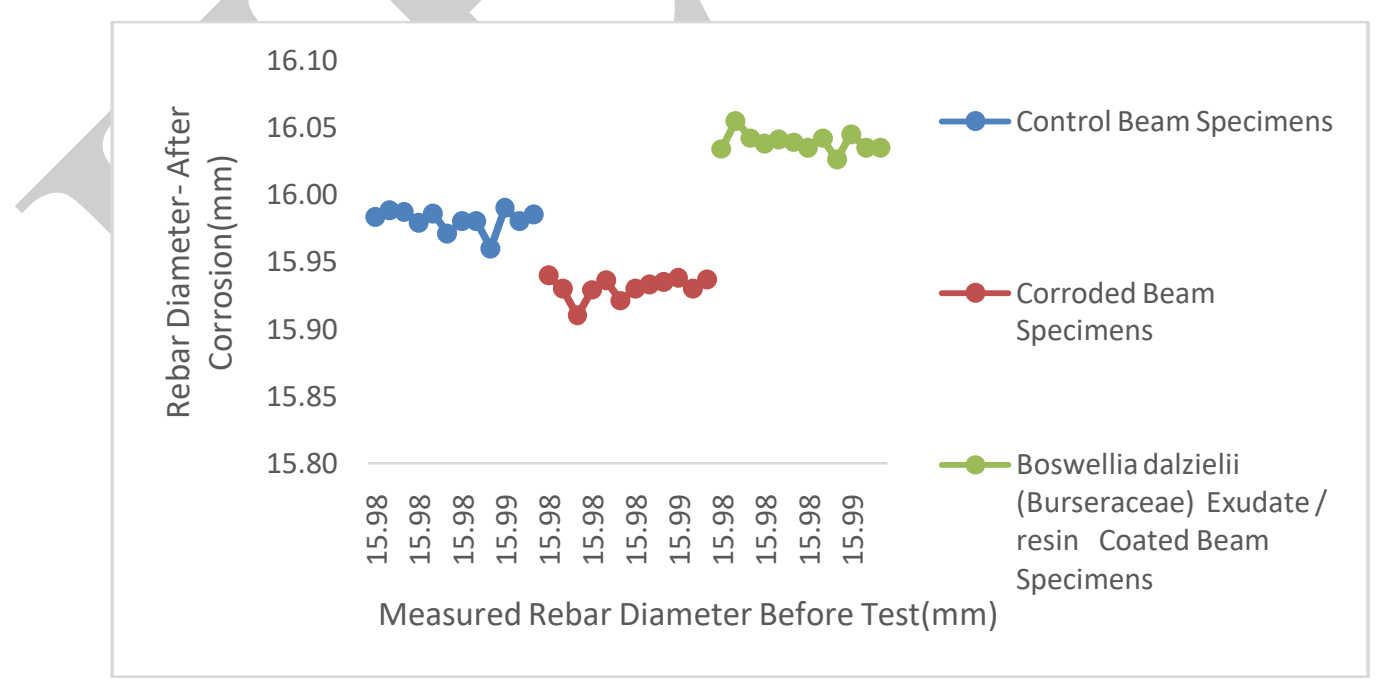

Figure 3.2: Measured Rebar Diameter Before Test versus Rebar Diameter- After Corrosion 
DOI : https://dx.doi.org/10.26808/rs.ed.i11v5.01

International Journal of Emerging Trends in Engineering and Development

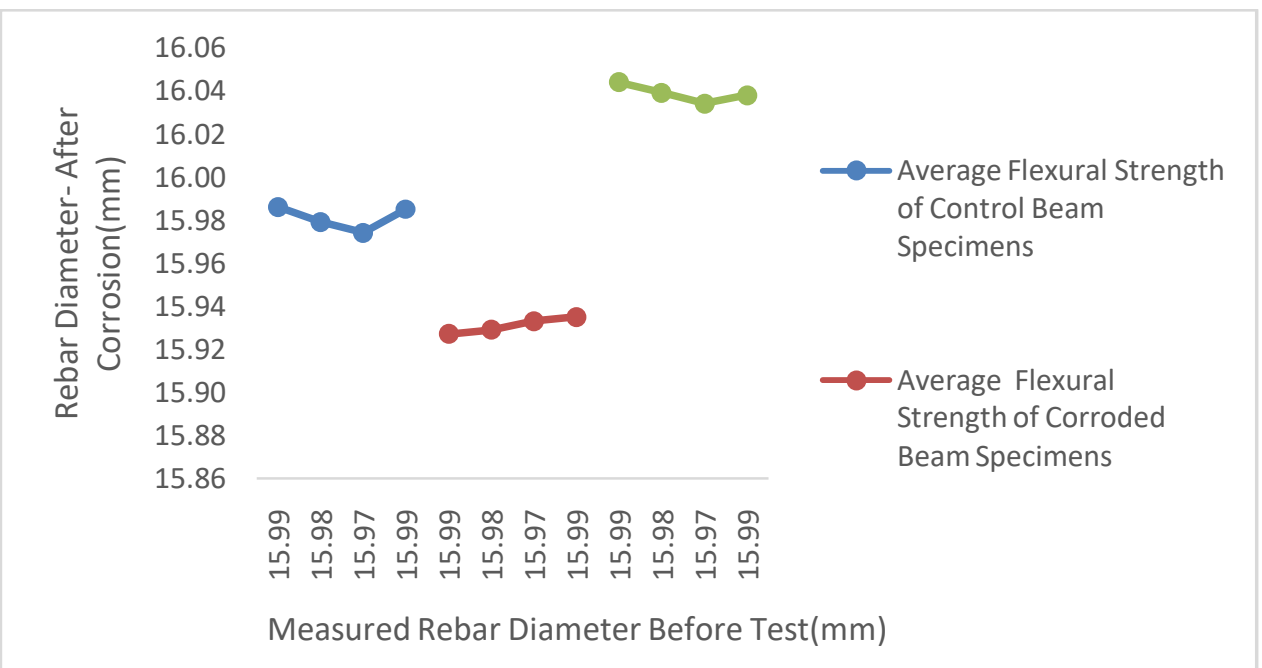

Figure 3.2A: Average Measured Rebar Diameter Before Test versus Rebar Diameter- After Corrosion

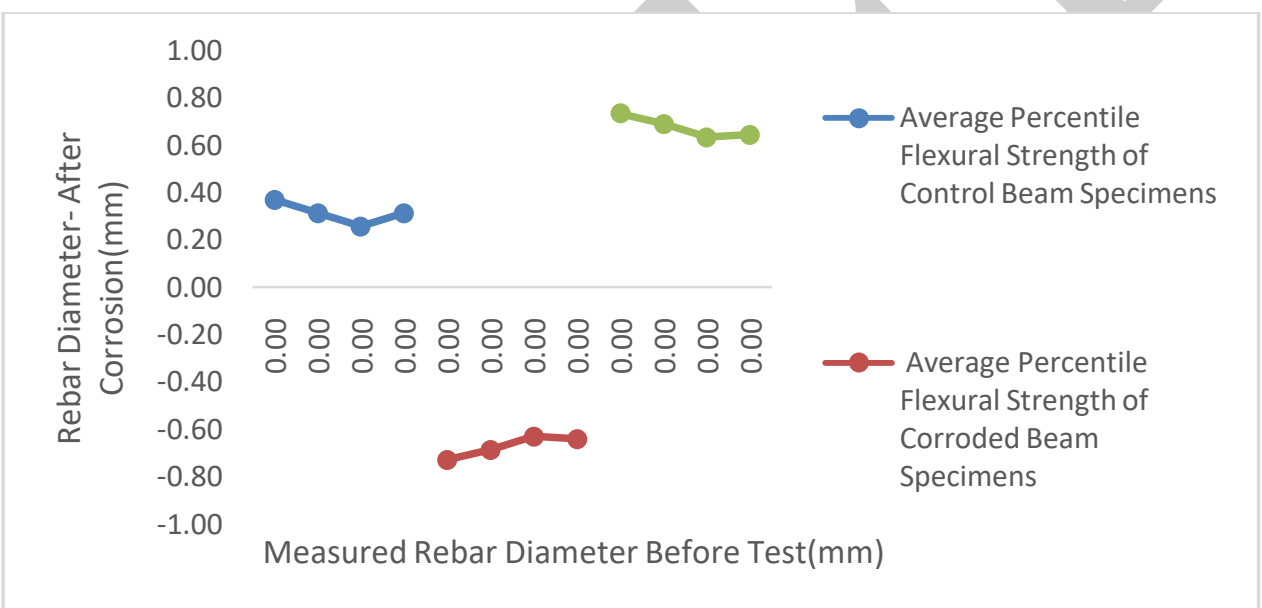

Figure 3.2B: Average Percentile Measured Rebar Diameter Before Test versus Rebar Diameter- After Corrosion

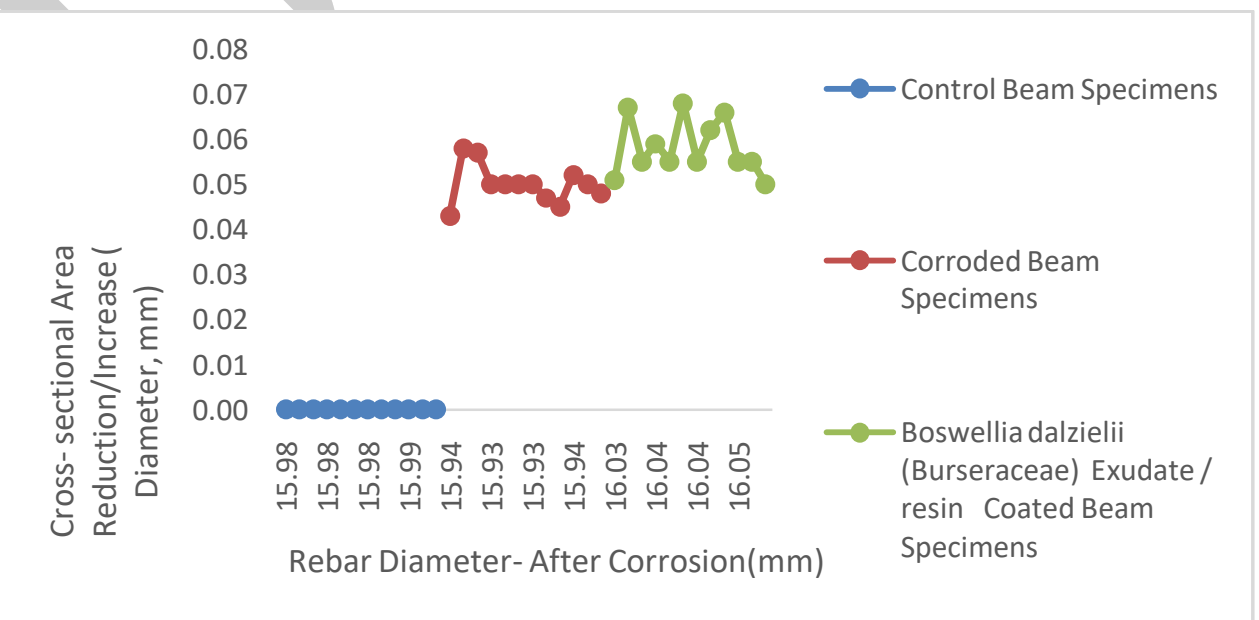

Figure 3.3: Rebar Diameter- After Corrosion versus Cross- sectional Area Reduction/Increase ( Diameter) 


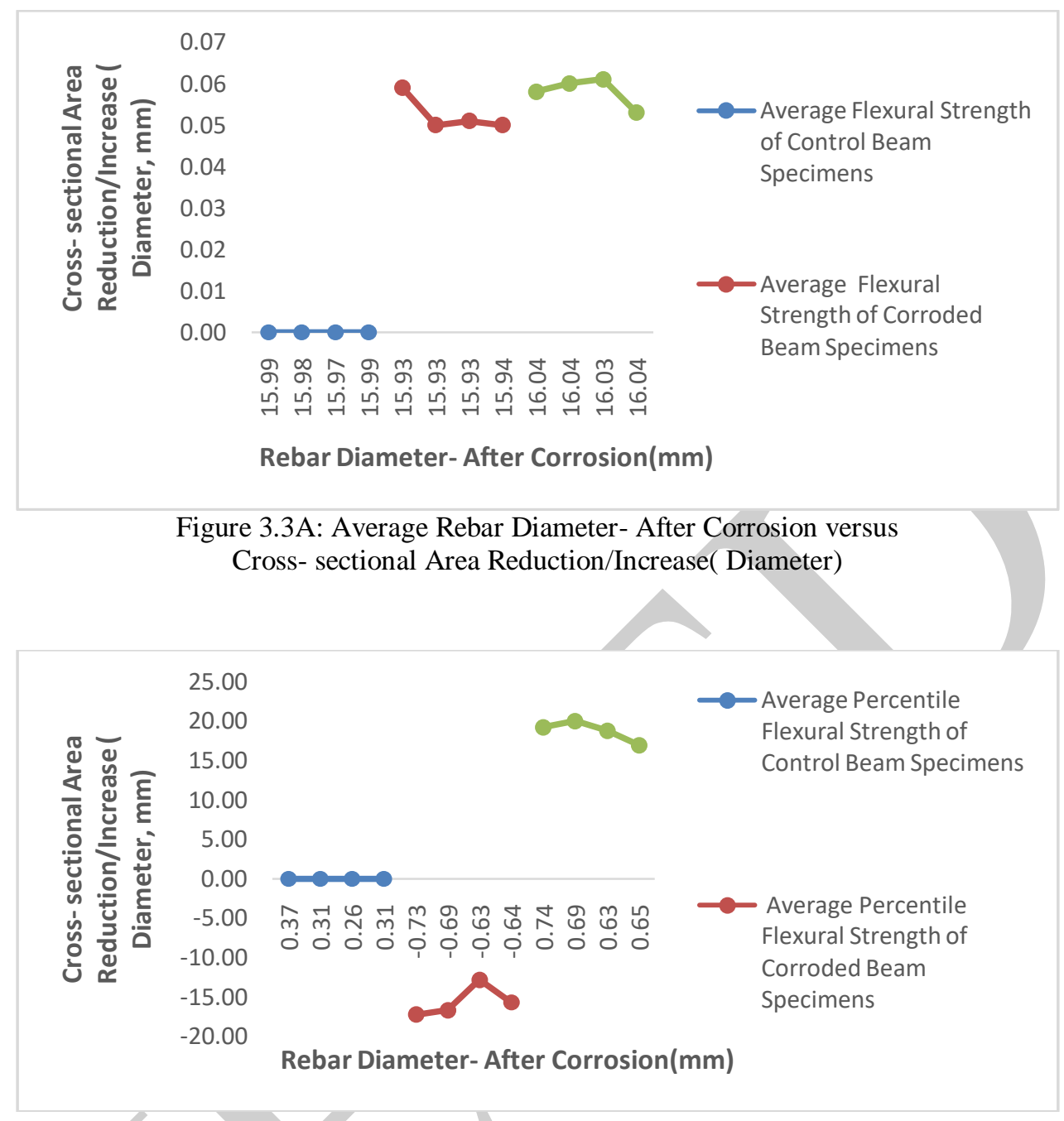

Figure 3.3B: Average Percentile Rebar Diameter- After Corrosion versus Cross- sectional Area Reduction/Increase (Diameter)

\subsection{Results of Ultimate Tensile Strength and Yield Strength}

Deformation increases, crack width, and stress in concrete and steel can be observed or measured in concrete structures as long as corrosion continues and affect their safety against damage or their behavior under operating conditions.

The ultimate load-carrying capacity of reinforced concrete structures does not only depend on the geometry, reinforcement (both quantity and location), material properties, and types of loads, but also the structural scheme. When a statically defined structure is subjected to steel corrosion, a reduction in the area of the steel in the most corroded region can lead to the formation of plastic hinges and eventually the failure mechanism. The results of the minimum and maximum mean and percentile values calculated in Tables 3.4 and 3.5 obtained from Tables 3.1-3.3 for the yield strength controlled sample values are $453.45 \mathrm{MPa}$ and $455.88 \mathrm{MPa}$ $(6.26 \%$ and $6.3 \%)$, the corroded sample was $426.59 \mathrm{MPa}$ and $429.02 \mathrm{MPa}(-5.93 \%$ and $5.89 \%)$ and the coated sample was $453.45 \mathrm{MPa}$ and $455.88 \mathrm{MPa}(6.26 \%$ and $6.3 \%)$.

The final tensile strength values of controlled samples were $595.31 \mathrm{MPa}$ and $599.8 \mathrm{MPa}$ $(3.36 \%$ and $3.38 \%)$, corroded samples were $575.82 \mathrm{MPa}$ and $580.32 \mathrm{MPa}(-3.57 \%$ and $3.54 \%)$ and coated samples $597.11 \mathrm{MPa}$ and $601.6 \mathrm{MPa}(3.67 \%$ and $3.7 \%)$. The results of the computations of the maximum evaluated value of both yield strength and tensile strength for the controlled sample are $6.3 \%$ and $3.38 \%$ for the corroded and coated values of $-5.89 \%$ and - 
$3.54 \%$ are the coated values at $6.3 \%$ and $3.7 \%$, respectively. Differential calculated mean and percentage values of yield strength and ultimate tensile strength are $(2.43 \mathrm{MPa}$ and $0.04 \%)$ and $(4.49 \mathrm{MPa}$ and $0.02 \%$ ) were examined, the corrosion value was $2.43 \mathrm{MPa}$ and $0.04 \%$ ) and (4.5MPa.) and $0.03 \%$, the values covered are $(2.43 \mathrm{MPa}$ and $0.04 \%)$ and $(4.4 \mathrm{MPa}$ and $0.03 \%)$. From the data obtained and compared, the yield strength limit and tensile strength limit of the corroded sample take into account the average and percentile values for failure loads with low applications. The damage caused a corrosive effect on the mechanical properties of reinforcing steel through surface modifications affecting the ribs and fibers, whereas the coated samples from the reference area (controlled samples) showed an increase in the mean and percentage values with higher loads carrying capacity. Exudates/resins show efficiency and effectiveness in protecting reinforced concrete structures exposed to corrosive media ([18], [19]. [20], [8] and [12]).

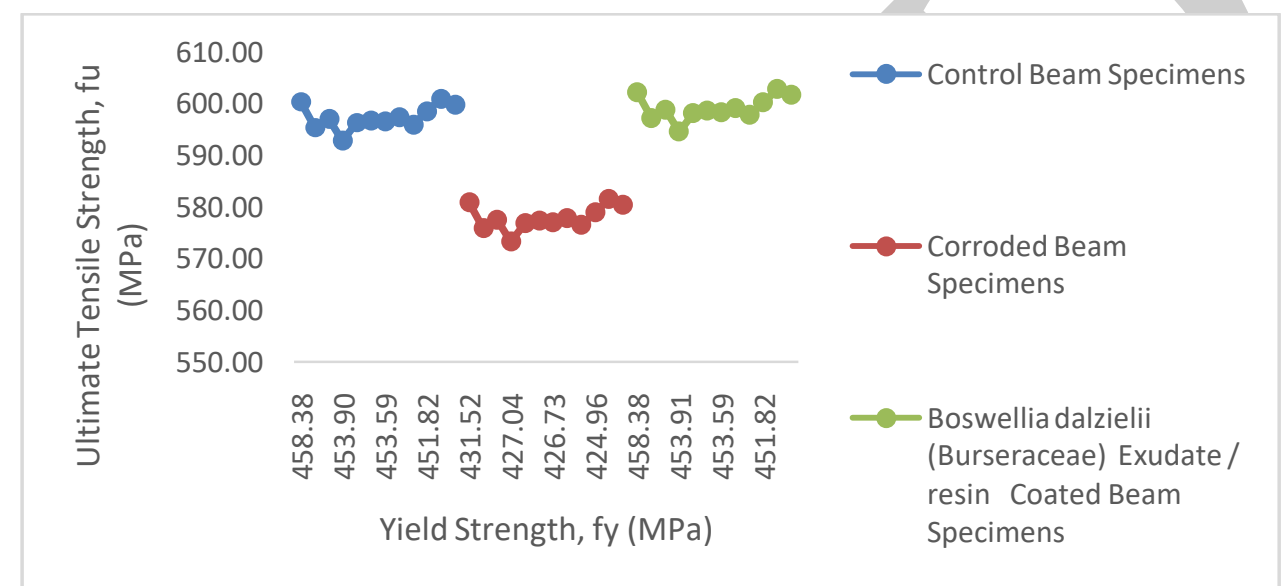

Figure 3.4: Ultimate Tensile Strength versus Yield Strength of Beam Specimens (Non-Corroded, Corrode and Resin Coated Specimens

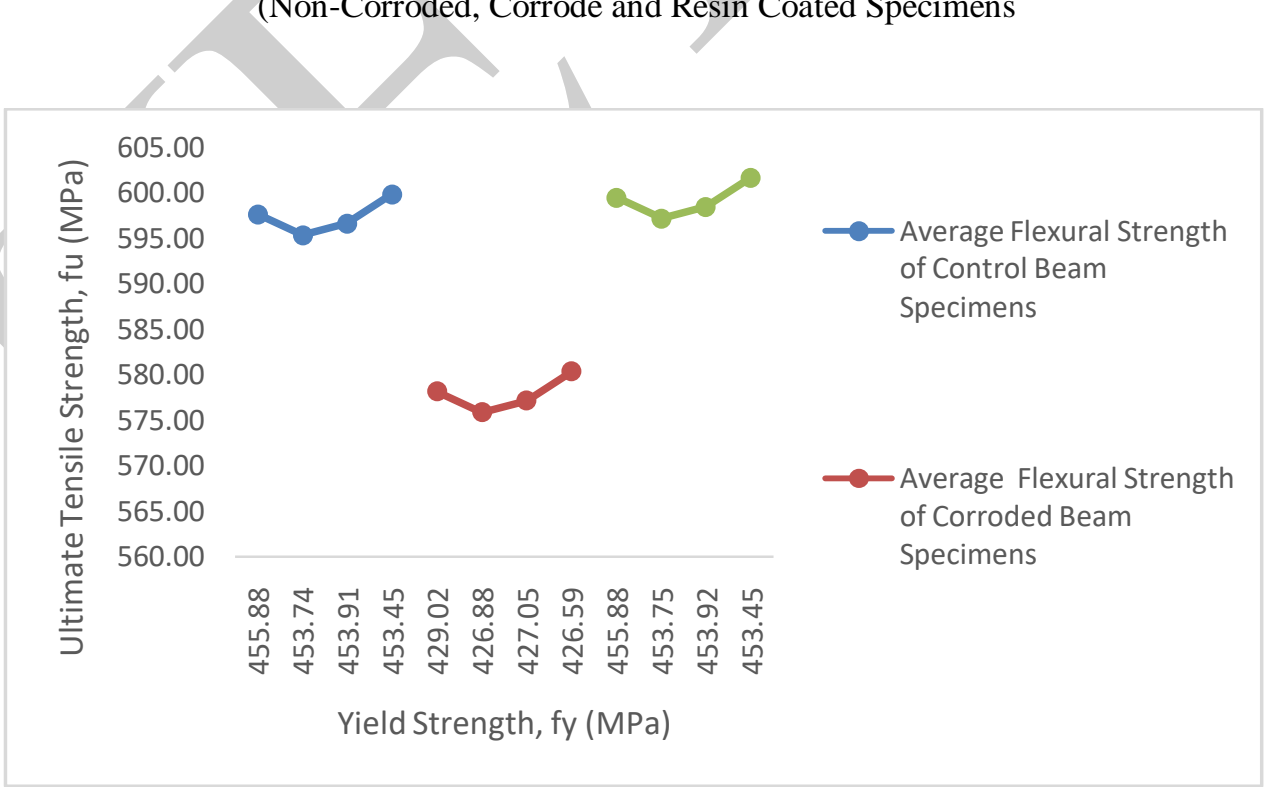

Figure 3.4A: Average Ultimate Tensile Strength versus Yield Strength of Beam Specimens

(Non-Corroded, Corrode and Resin Coated Specimens 


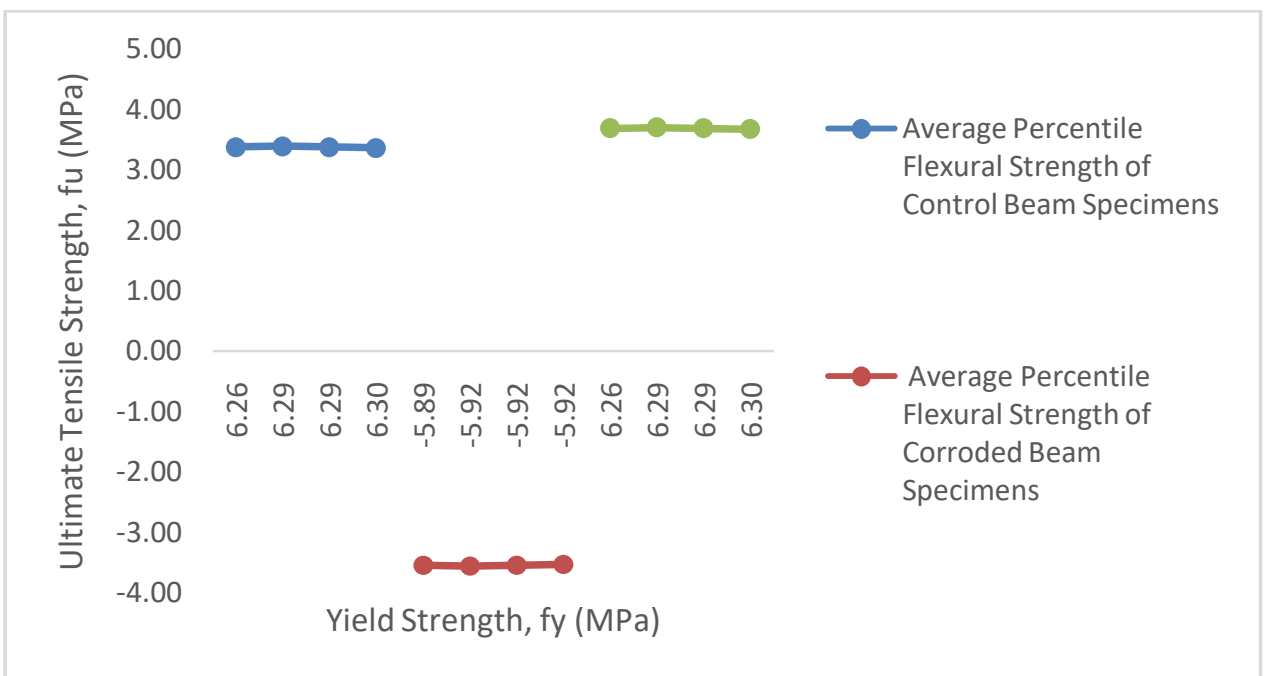

Figure 3.4B: Average percentile Ultimate Tensile Strength versus Yield Strength of Beam Specimens (Non-Corroded, Corrode and Resin Coated Specimens

\section{Results of Strain Ratio, Elongation, Rebar Weights- Before and After Corrosionn and Weight Loss /Gain of Steel}

Reinforcement corrosion is widely accepted as a major cause of premature wear in reinforced concrete structures. During the corrosion process, the weight of the material decreases as the depth of the corrosion/dimple layer increases. The corrosion rate of reinforcement has a significant influence on the flexural strength, deformation behavior, ductility, bond strength, and the type of damage to the reinforced concrete structure. Corrosion damages the surface layer of steel reinforcement and causes a decrease in mechanical properties in terms of strength and ductility.

The results of the calculation of the minimum and maximum mean and percentage values in Tables 3.4 and 3.5 are obtained from Tables 3.1-3.3 the elongation values obtained from the controlled sample are 1.31 and $1.32(-2.75$ and $-2.72 \%)$, samples that Corrosion was reported as 1.35 and $1.36(2.49 \%$ and $2.51 \%$ and $2.51 \%)$, coated sample values were 1.32 and 1.33 ($2.45 \%$ and $-2.43 \%$ respectively).

It was found that the ratio of the maximum calculated strain ratio for the mean and percentile values for the controlled was $-2.72 \%$ compared to the corroded and overlaid values of $2.51 \%$ and $-2.43 \%$, respectively. The mean differential and percentile values obtained for the control was $(0.01$ and $0.03 \%)$, corrosion values $(0.01$ and $0.02 \%)$ and values with coating $(0.01$ and $0.02 \%$ ). The results showed that the corroded samples had a higher elongation ratio due to lower damage loads and higher yields, whereas coatings had a higher percentage of load application with lower yields. Lower loads and higher yield and deformation strengths are the results of the effect of corrosion on the mechanical properties of reinforcing steel, which affects the interface, surface modification, fiber reduction, and rib removal. The above factors have reduced the load-carrying capacity of work-related reinforced concrete structures ([18], [19], [20], [8] and [12]).

The results of the minimum and maximum strain values for the controlled sample were $8.55 \%$ and $8.97 \%(-13.28 \%$ and $-12.92 \%)$, corrosion values were $18.44 \%$ and $18.86 \%$ $(20.27 \%$ and $20.62 \%)$, the values of the coated samples were $(8.48 \%$ and $8.9 \%)-23.99 \%$ and $-23.82 \%$. The maximum comparison value for controlled samples was $-12.92 \%$ compared to corroded and coated samples of $20.62 \%$ and $-23.82 \%$, respectively. The mean differential and percentile values obtained for the controlled samples were $(0.42 \%$ and $0.36 \%)$, corroded values $(0.42 \%$ and $0.35 \%)$, and coated values $(0.42 \%$ and $0.17 \%)$ respectively. In 
comparison, the corroded samples showed higher stress values and higher elongation rates, whereas the failure state of coated samples was lower load and reduced elongation. The effect of corrosion impairs the mechanical properties of reinforcing steel, leading to higher fracture rates at low loads; coated samples show a range of values closer to the reference (controlled sample). The application of exudates materials to rebar has reduced the scourge and tendency of corrosive attack to be exposed to reinforced concrete structures in heavy marine coastal areas in connection with works ([18], [19], [20], [8] and [12]).

The rebar unit weight of the minimum and maximum average and percentage values before the test, calculated in Tables 3.4 and 3.5 and obtained from Tables 3.1-3.3 of the unit weight parameters before and after corrosion testing, the values of the samples examined were 1.74 $\mathrm{kg}$ and $11.77 \mathrm{Kg}(0.063 \% 0.068 \%)$, corrosion values are $1.74 \mathrm{~kg}$ and $1.77 \mathrm{~kg}(0.064 \%$ and $0.066 \%)$ and the values included are $1.74 \mathrm{~kg}$ and $1.77 \mathrm{~kg}(0.065 \%$ and $0.067 \%)$ and weight of anchor - after corrosion $(\mathrm{Kg})$, the values obtained from the mean and percentile values of the minimum and maximum were $1.74 \mathrm{~kg}$ and $1.77 \mathrm{~kg}(2.45 \%$ and $2.49 \%)$, the corrosion value was $1.7 \mathrm{~kg}$ and $1.73 \mathrm{~kg}(-5.29 \%$ and $-5.25 \%)$, coated values were $1.8 \mathrm{~kg}$ and $1.82 \mathrm{~kg}(5.54 \%$ and $5.59 \%$ ). The difference values obtained for the mean and percentile of the controlled samples were $(0.03$ and $0.04 \%)$, corroded values $(0.03 \mathrm{~kg}$ and $0.04 \%)$, and coated values $0.02 \mathrm{~kg}$ and $0.05 \%)$.

The results of weight loss/gain of steel minimum and maximum average and percentile values are controlled (100\%) for controlled samples resulting in its pooling in freshwater with no traces of corrosion attacks, the corroded sample values are $0.04 \mathrm{~kg}$ and $0.04 \mathrm{~kg}(-20.76 \%$ and $-14.29 \%$ ), the coated samples are $0.05 \mathrm{~kg}$ and $0.05 \mathrm{~kg}(16.67 \%$ and $26.19 \%)$. The calculated data for the maximum percentage of reinforcement beam weight before corrosion test for controlled, corroded, and coated values were $0.068 \%, 0.066 \%$, and $0.067 \%$. The maximum unit weight loss/gain of rebar comparative value recorded after the corrosion test for the controlled sample remained the same, without any trace of corrosive effect, because it was incorporated in freshwater; values of $-5.25 \%$ and $5.59 \%$ were achieved for corrosive and coated samples. The percentage of maximum weight loss/gain for corroded and coated samples was $14.29 \%$ and $26.19 \%$, respectively. The calculated data showed a decrease in the value of the corroded sample as a result of the corrosive attack, which led to a decrease in the registered weight, whereas the coated sample showed an increase in weight due to the different coating thickness compared to the reference value of the controlled sample from the works of ([18], [19], [20], [8] and [12]).

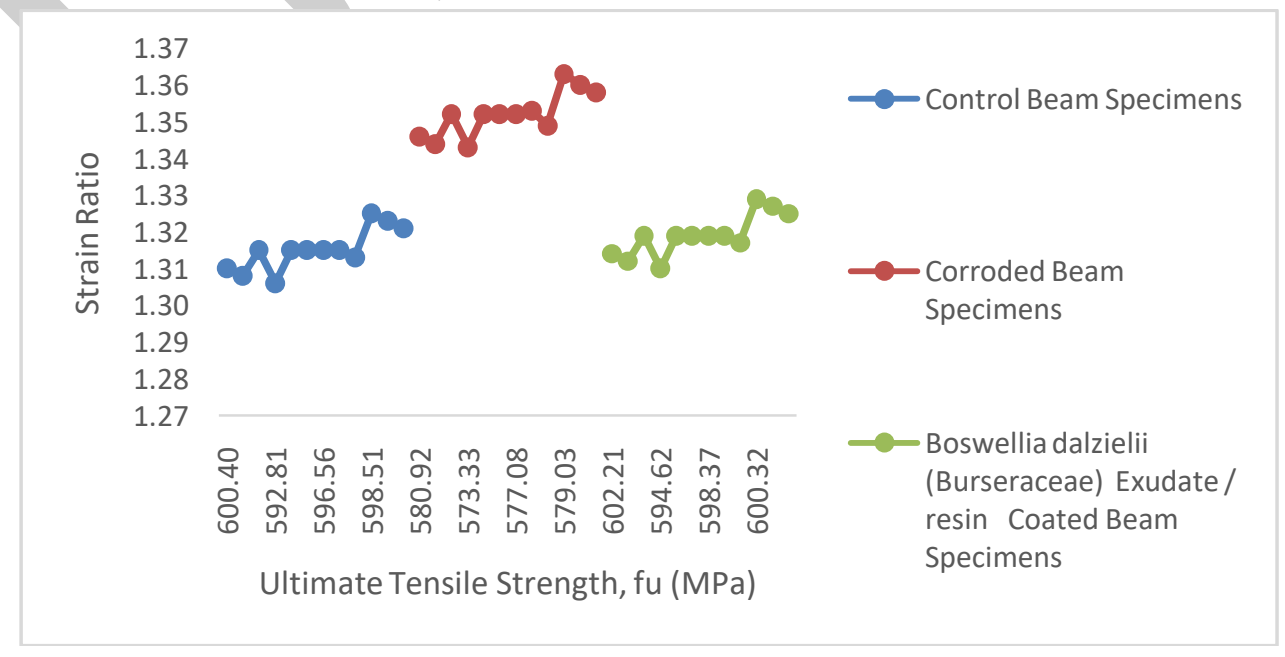

Figure 3.5: Ultimate Tensile Strength versus Strain Ratioof Beam Specimens 


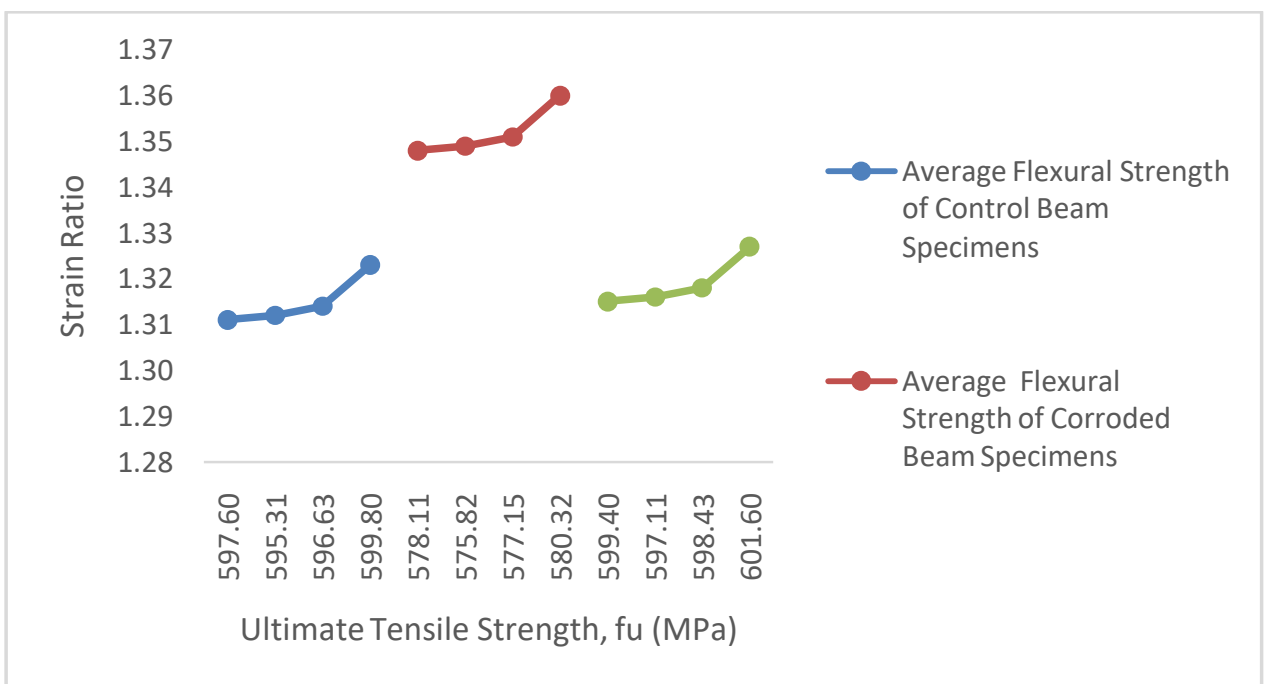

Figure 3.5A: Average Ultimate Tensile Strength versus Strain Ratio of Beam Specimens

(Non-Corroded, Corrode and Resin Coated Specimens

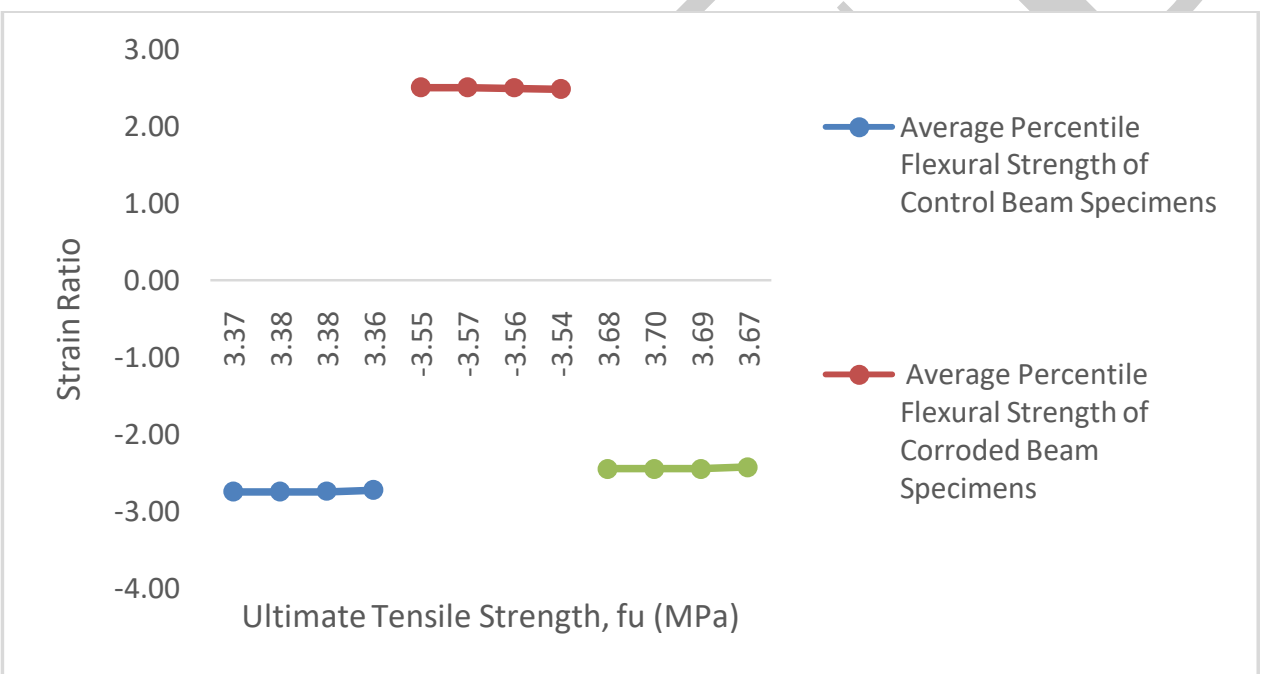

Figure 3.5B:Average Percentile Ultimate Tensile Strength versus Strain Ratio of Beam Specimens

(Non-Corroded, Corrode and Resin Coated Specimens

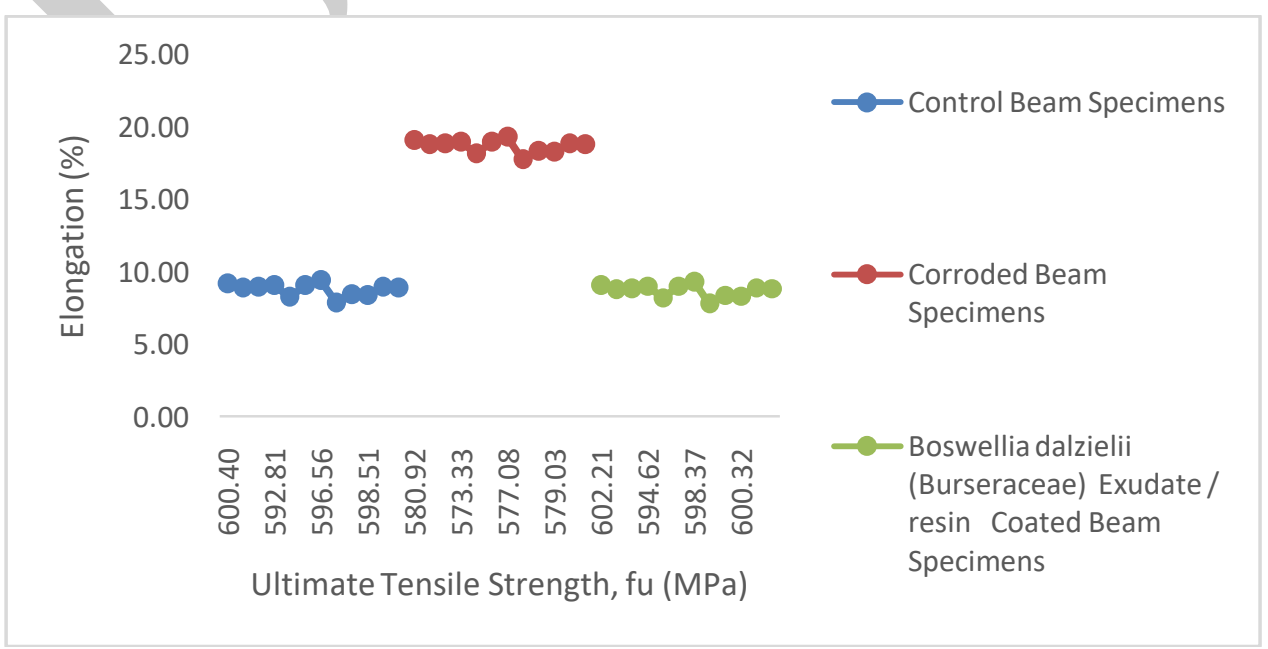

Figure 3.6: Ultimate Tensile Strength versus Strain Ratio of Beam Specimens (Non-Corroded, Corrode and Resin Coated Specimens 
DOI : https://dx.doi.org/10.26808/rs.ed.i11v5.01

International Journal of Emerging Trends in Engineering and Development

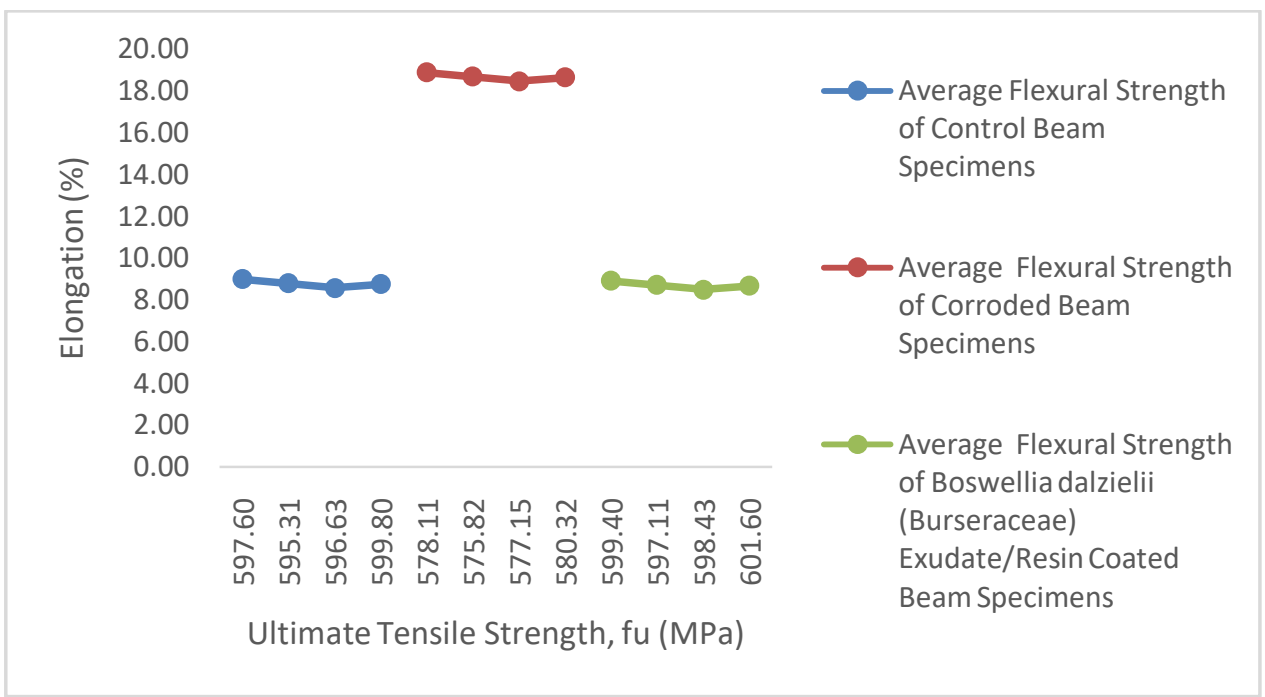

Figure 3.6A: Average Ultimate Tensile Strength versus Strain Ratioof Beam Specimens

(Non-Corroded, Corrode and Resin Coated Specimens

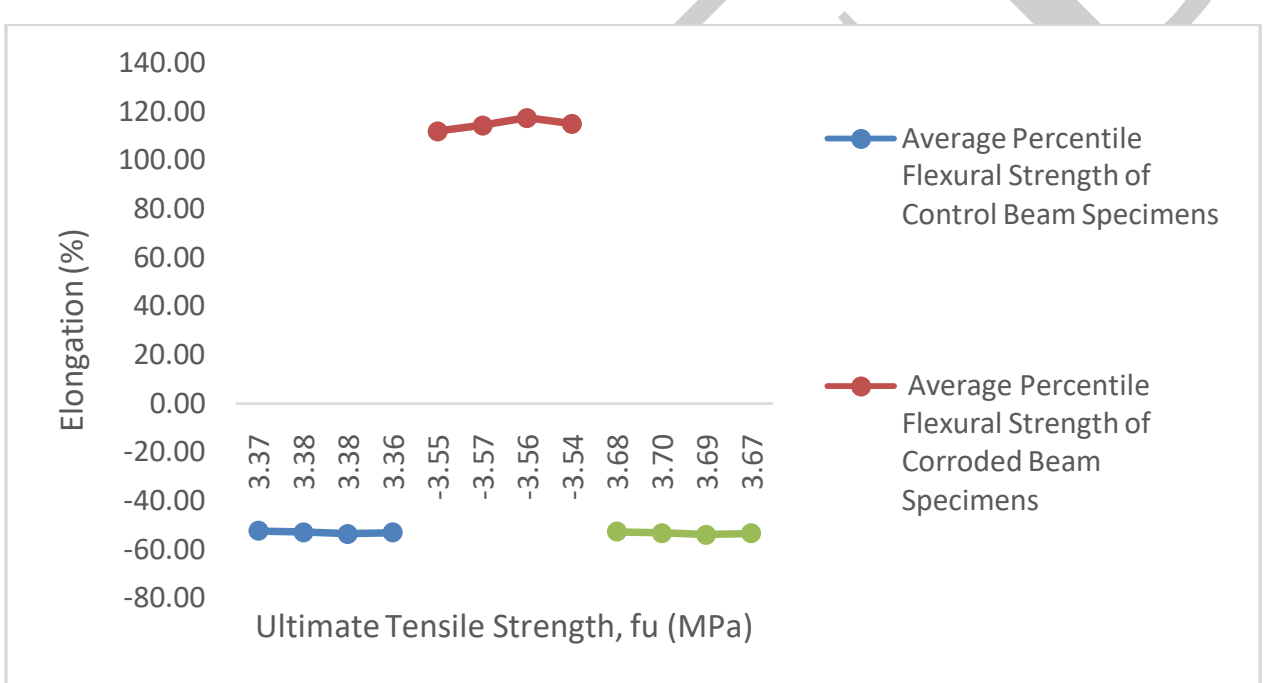

Figure 3.6B:Average Percentile Ultimate Tensile Strength versus Strain Ratioof Beam Specimens (Non-Corroded, Corrode and Resin Coated Specimens

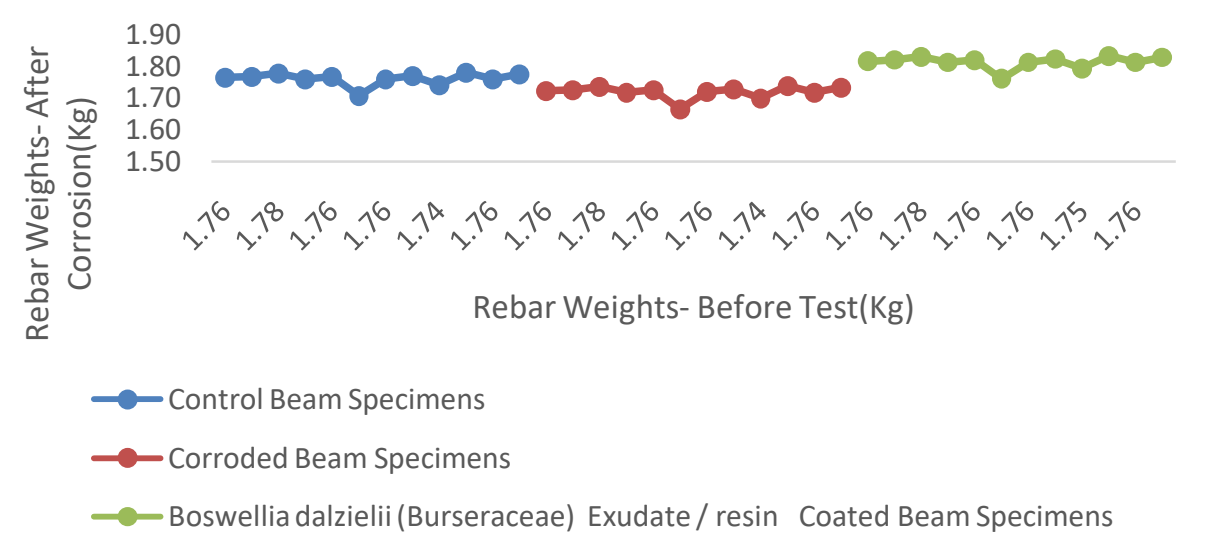

3.7: Rebar Weights- Before Test versus Rebar Weights- After Corrosion (Non-Corroded, Corrode and Resin Coated Specimens 
DOI : https://dx.doi.org/10.26808/rs.ed.i11v5.01

International Journal of Emerging Trends in Engineering and Development

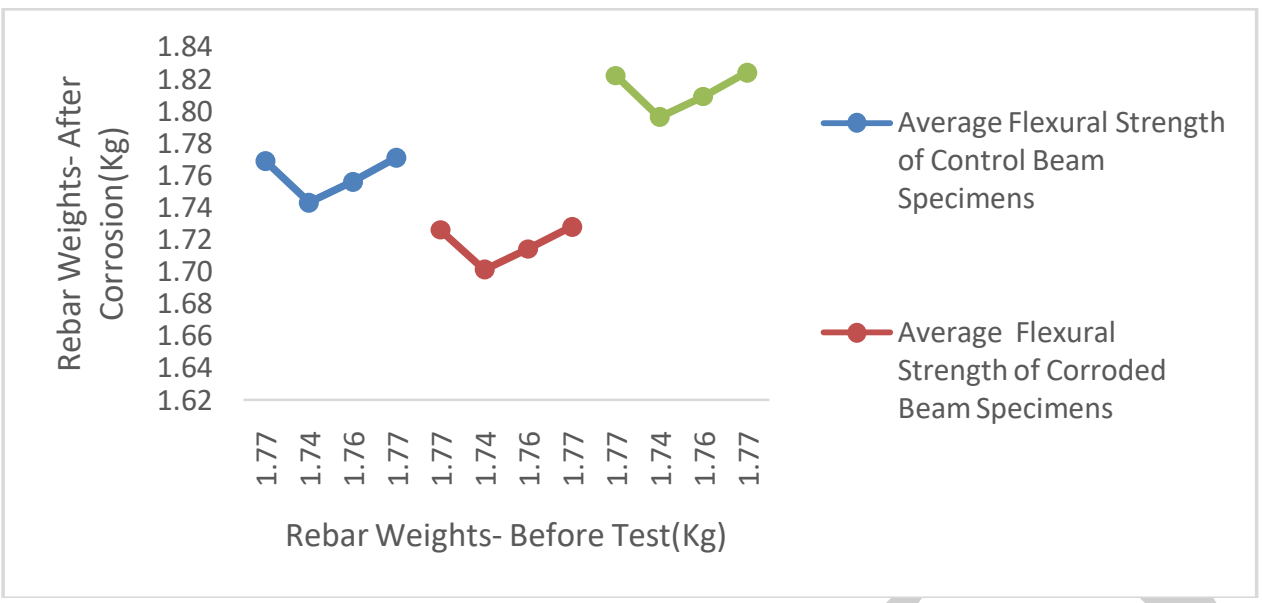

Figure 3.7A: Average Rebar Weights- Before Test versus Rebar Weights- After Corrosion (Non-Corroded, Corrode and Resin Coated Specimens

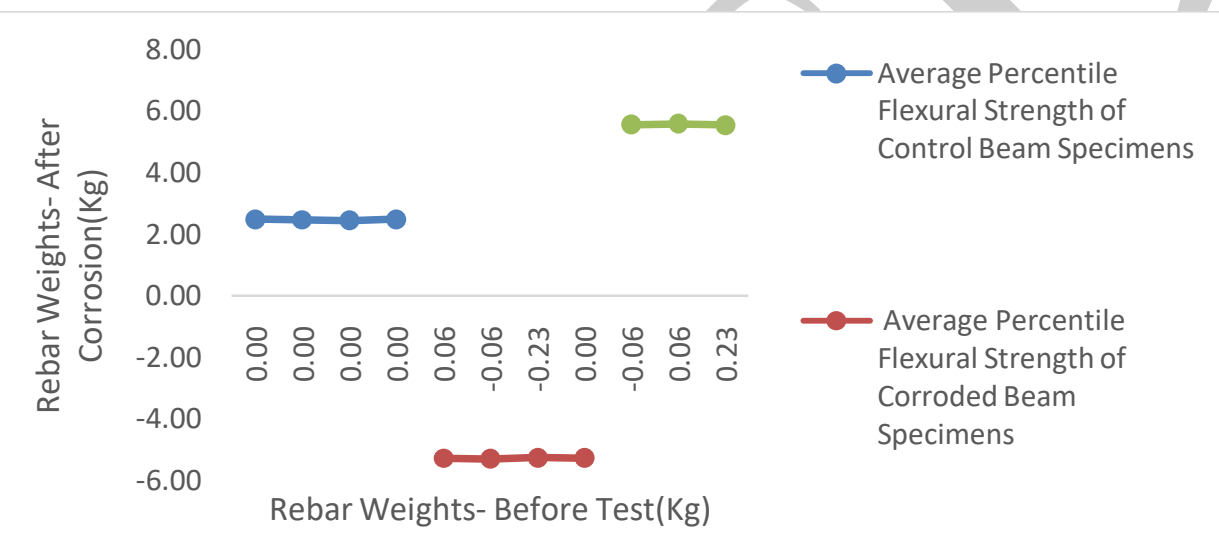

Figure 3.7B: Average Percentile Rebar Weights- Before Test versus Rebar Weights- After Corrosion (Non-Corroded, Corrode and Resin Coated Specimens

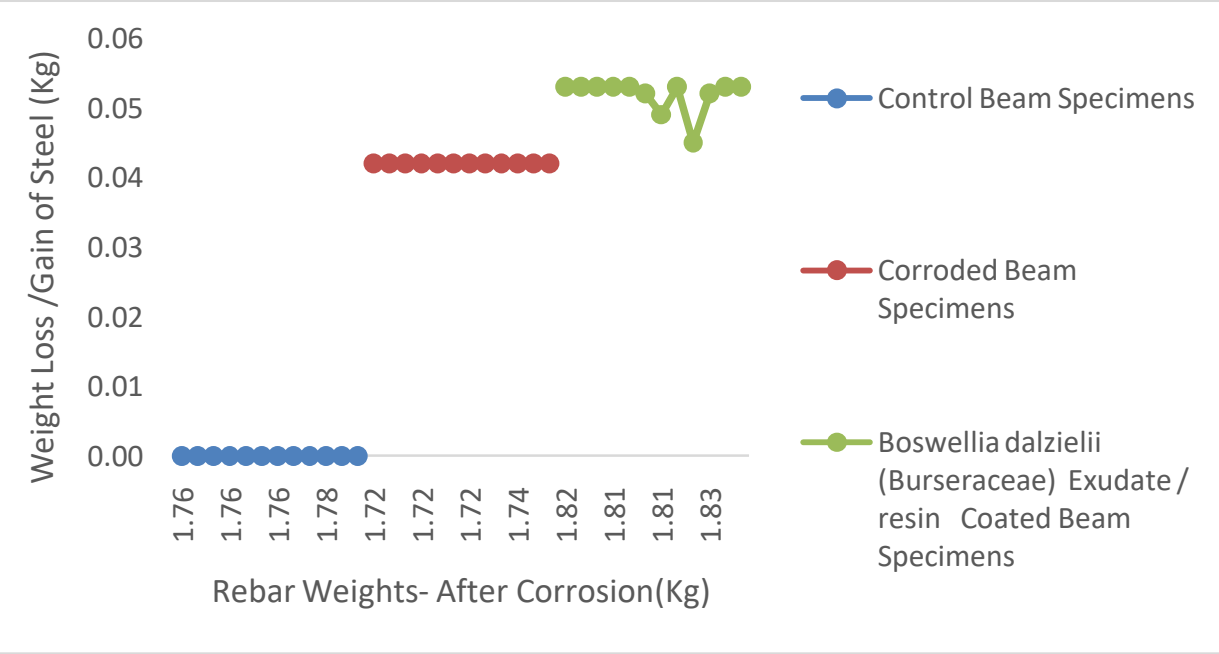

Figure 3.8: Weights- After Corrosion versus Weight Loss /Gain of Steel (Kg)

(Non-Corroded, Corrode and Resin Coated Specimen 


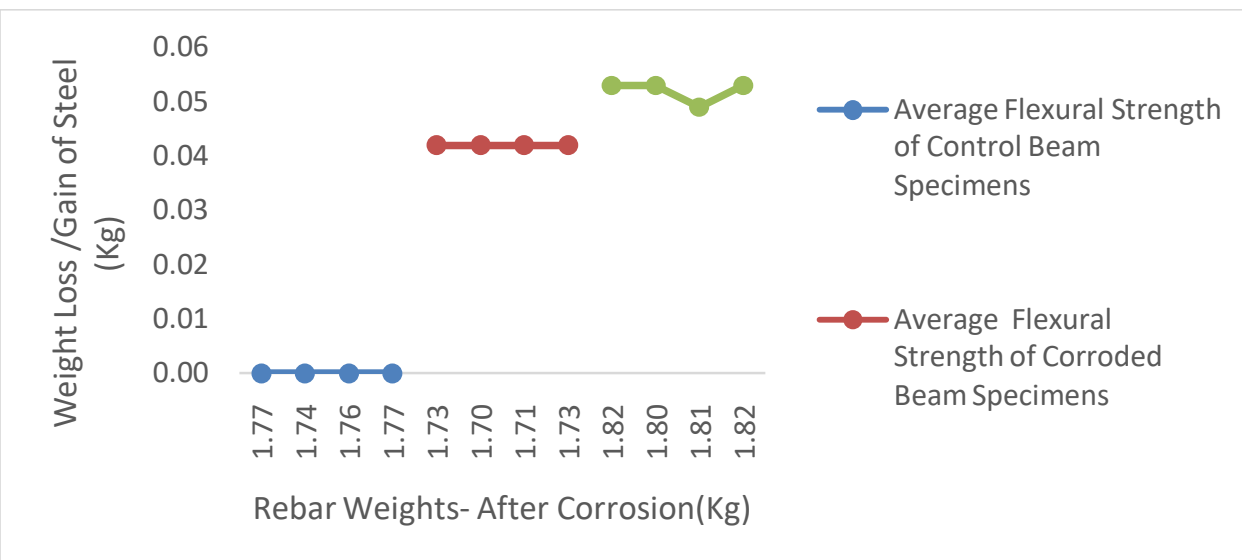

Figure 3.8A: Average Weights- After Corrosion versus Weight Loss /Gain of Steel (Kg)

(Non-Corroded, Corrode and Resin Coated Specimens

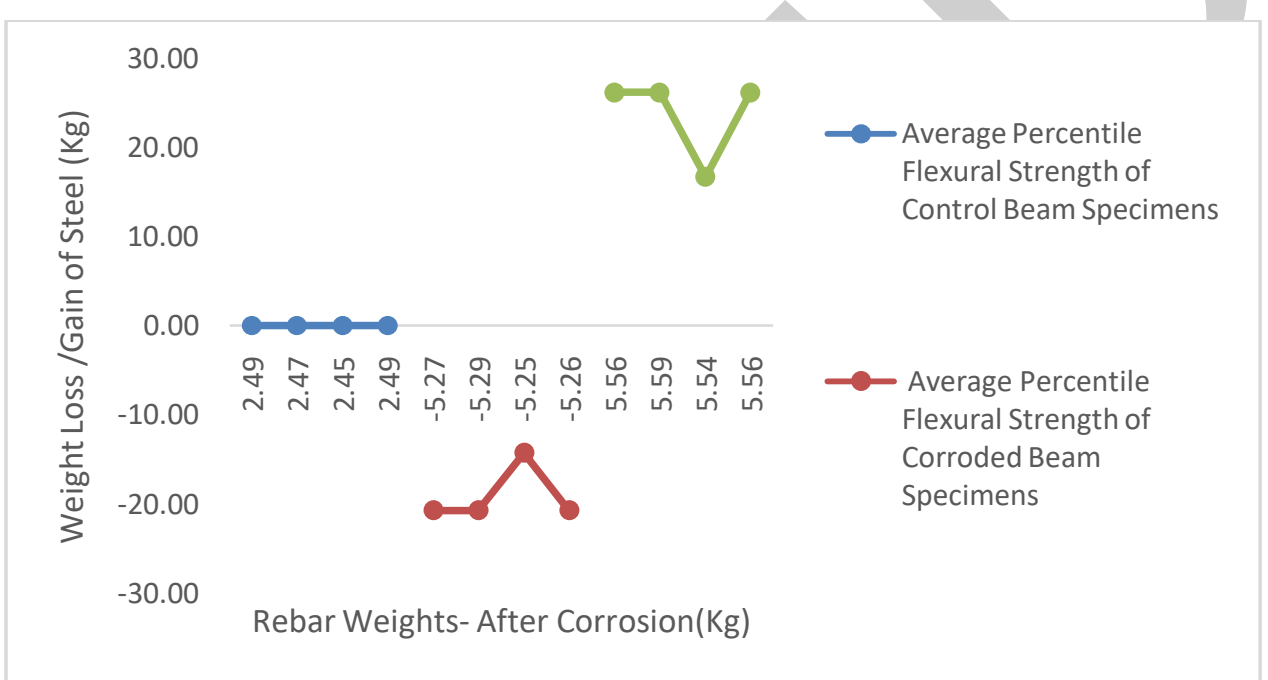

Figure 3.8B: Average Percentile Weights- After Corrosion versus Weight Loss /Gain of Steel (Kg)

(Non-Corroded, Corrode and Resin Coated Specimens

\subsection{CONCLUSION}

The experimental results obtained are summarized as follows:

1. The results showed that exudates/resin is a corrosion protective material in reinforced concrete structures exposed to corrosive media, with high resistance and as a sealing membrane against the effects of corrosion.

2. The results obtained showed the effect of corrosion on the mechanical properties of reinforcing steel with a decrease in the diameter of the reinforcement in the corroded sample, while the coated sample showed an increase due to the thickness of the exudates paste layer.

3. Reduced cross-sectional area due to corrosive effects on reinforced concrete structures built in marine coastal environments and work-related increase in exudates/resin

4. Exudates / resins have been proven to be effective and efficient in protecting reinforced concrete structures exposed to corrosive environments.

5. Results show lower strain loads for controlled and coated samples with lower values than for corroded samples with higher strain loads and increased values compared to reference ranges (controlled) and coated samples.

6. The results of the comparison of flexural strength and elongation load in the center of the corroded sample show the effect of corrosion on the mechanical properties of reinforcing steel with curved reinforcement, high surface modification, low load carrying capacity, tear resistance and high deformation of reinforcing steel. 
7. The combined results of the controlled sample on the corroded sample show that the controlled sample replaces the properties of the corroded sample with low flexural elongation, low deviation in the medium elongation range, normal limits, high breaking strength, low elongation / elongation ratio. 8. Corrosion test results show high flexural stresses; deformation rate is higher than the average range.

\section{REFERENCES}

1. Al-Sulaimani, G. J. Kaleemullah, M. Basunbul, I. A. and Rasheeduzzafar, A. (1990). Influence of Corrosion and Cracking on Bond Behavior and Strength of Reinforced Concrete Members. ACI Structural Journal, 87: 220-231.

2. Mangat, P. and Elgarf, M. S. (1999). Flexural Strength of Concrete Beams with Corroding Reinforcement. ACI Structural Journal, 96:149-158.

3. Almusallam, A. Ahmed, S. Gahtani, A. and Rauf, A. (1995). Effect of Reinforcement Corrosion on Bond Strength. Construction and Building Materials, 10:123-129.

4. Cabrera, J. G. (1996). Deterioration of Concrete due to Reinforcement Steel Corrosion. Cement and Concrete Composites, 18(1):47-59.

5. Auyeung, Y. Balaguru, P. and Chung, L. (2001). Bond Behavior of Corroded Reinforcement Bars. ACI Materials Journal, 97(2): 214-220.

6. Amleh, L. and Mirza, M. S. (1999). Corrosion Influence on Bond between Steel and Concrete. ACI Structural Journal, 96: 415-423.

7. Fang, C. Lundgren, K. Chen, L. and Zhu, C. 2004. Corrosion Influence on Bond in Reinforced Concrete. Cement and Concrete Research, 34: 2159-2167.

8. Ouglova, A. Berthaud, Y. Foct, F. François, M. Ragueneau, F. and Petre-Lazar, I. (2008). The Influence of Corrosion on Bond Properties between Concrete and Reinforcement in Concrete Structures. Materials and Structures, 41:969-980.

9. Charles, K. Latam, L. P. Ugo, K. (2018). Effect of Corrosion on Bond between Steel and Concrete of Corroded and Inhibitive Reinforcement Embedded in Reinforced Concrete Structures in Accelerated Corrosive Medium. International Journal of Scientific \& Engineering Research, (9)4:803-813.

10. Charles, K. Okabi, I. S. Terence, T. T.W. and Kelechi, O. (2018). Comparative Investigation of Pull-Out Bond Strength Variance of Resins $\backslash$ Exudates Inhibitive and Corroded Reinforcement Embedded in Reinforced Concrete Structures, Exposed to Severely Environment. International Journal of Scientific and Engineering Research, (9)4:641-654.

11. Charles, K. Gbinu, S. K. and Achieme, L. O. (2018). Effect of Corrosive Environment on Reinforced Concrete Structures Pullout Bond Strength of Corroded and Resins / Exudates Coated Reinforcement. International Journal of Scientific \& Engineering Research, (9)4:814 - 824.

12. Otunyo, A.W and Kennedy, C. (2018). Effectiveness of Resins/Exudates of Trees in Corrosion Prevention of Reinforcement in Reinforced Concrete structures, Nigerian Journal of Technology, 37:78-86.

13. Sule, S., Charles, K., Nwaobakata, C. ( 2019). Mechanical Interlock between Steel Ribs and Concrete Exposed to Niger Delta Coastal Marine Region of Nigeria. International Journal of Emerging Trends in Engineering and Development, 6(9): 15 - 23

14. Gilbert D. G., Nelson, T. A., and Charles, K.. (2019). Evaluation of Residual Yield Strength Capacity of Corroded and Exudates / Resins Coated Reinforcing Bars Embedded in Concrete. European Journal of Advances in Engineering and Technology, 6 (9): 48-56.

15. TrustGod, J. A., Kennedy, C. and Gilbert, D. R. (2019). Flexural Residual Capacity and Ultimate Yield Strength of Corroded and Inhibitive Reinforced Concrete Beams in Corrosive Environment. International Journal of Science and Engineering Investigations, 8 (9): 121 - 129.

16. Nwaobakata, C., Charles, K., Sule, S. (2019). Residual Strength Capacity of Corroded and Coated Reinforcing Bars Corrosion Performance on the Flexural Strength of Reinforced Concrete Members. International Journal of Civil and Structural Engineering Research, 7 (2): 13-23.

17. Charles, K., Letam, L. P., Nzidee, L. F. (2019). Flexural Strength of Non-coated and Coated Reinforcement Embedded in Concrete Beam and pooled in Corrosive Solution. Journal of Multidisciplinary Engineering Science and Technology, 6 (9):10736 - 10746, 
18. Kanee, S., Petaba, L. D., Charles, K. (2019). Inhibitory Action of Exudates / Resins Extracts on the Corrosion of Steel Bar Yield Strength in Corrosive Media Embedded in Concrete. European Academic Research , 7 (7): 3381 - 3398.

19. Charles, K., Damini, R. G., Toscanini, D. S. (2019). Behavioral Failure Load and Midspan Deflection of Reinforced Concrete Beams of Corroded and Coated Members. Global scientific journal, 7 (9): 1155 - 1167.

20. Charles, K., Philip, Kpae. F. O., Letam, L. P. (2019). Corrosion Probability of Reinforcing Steel in Concrete in Accelerated Corrosion Environment of Applied Currents Potential. Journal of Multidisciplinary Engineering Science and Technology, 6 (9): 10716 - 10726

21. Fernandez, I., Bairán J. M., and Marí, A. R. (2015). Corrosion Effects on the Mechanical Properties of Reinforcing Steel Bars. Fatigue and $\sigma-\varepsilon$ Behavior. Construction and Building Materials, 101: 772-783.

22. 882; 1992- Specification for Aggregates from Natural Sources for Concrete. British Standards Institute. London, United Kingdom.

23. BS EN 196-6; 2010- Methods of Testing Cement. Determination of fineness, British Standards Institute. London, United Kingdom, 2010.

24. BS 3148; 1980 - Methods of test for Water for Making Concrete. British Standards Institute. London, United Kingdom.

25. BS 4449:2005+A3; 2010 - Steel for Reinforcement of Concrete. British Standards Institute. London, United Kingdom.

26. BS EN 12390-2; 2005 - Testing Hardened Concrete: Flexural Strength Test of Specimens, British Standards Institute. London, United Kingdom,

27. Liu, T. and Weyers, R.W. (1998). Modeling the Dynamic Corrosion Process in Chloride Contaminated Concrete Structures, Cement and Concrete Research, 28(3): 365-379.

28. Fernandez, I., Bairán J. M., and Marí A. R. (2015): "Corrosion Effects on the Mechanical Properties of Reinforcing Steel Bars. Fatigue and $\sigma-\varepsilon$ Behavior. Construction and Building Materials, 101:772-783. 